\title{
De Arqueología Mozárabe. II. De sus iglesias y documentos epigráficos*
}

\author{
On Mozarabic Archaeology. II. About churches and epigraphic documents
}

\author{
Rafael Azuar**
}

\begin{abstract}
RESUMEN
Continuando el artículo anterior, efectuamos una revisión de la arquitectura, del arte y de los documentos epigráficos de los mozárabes, desde un análisis crítico de la cultura material de los cristianos en al-Andalus bajo el califato de Córdoba (siglo X)
\end{abstract}

Palabras clave: Al-Andalus, Mozárabes, Arquitectura, Epigrafía, Arqueología

En el artículo anterior (AZUAR, 2015), afrontamos una necesaria revisión del mobiliario ritual y litúrgico de los mozárabes, elaborado en su día y dado a conocer, hace ahora un siglo, por M. Gómez-Moreno en su artículo cuyo título encabeza nuestra investigación (1913). Listado fluctuante de objetos que apenas constituye sólo una parte o facies del registro arqueológico documental aparecido en el mencionado capítulo IX, denominado "Museo Mozárabe", de su obra posterior, en el que también se aportaba un importante número de inscripciones y la relación de los códices o manuscritos conservados en aquel momento que, junto con el estudio de iglesias mozárabes (Gómez-Moreno, 1919), conformaban la base artefactual de la cultura material de una pretendida "Arqueología Mozárabe".

Con el fin de completar aquel primer análisis, -y manteniendo el contexto cronológico

\begin{abstract}
Continuing the previous article, we do a review of the Architecture, Art and Epigraphical documents of the Mozarabs, from a critical analysis of the material culture of the Christians in al - Andalus, under the Caliphate of Cordoba (X AD century)
\end{abstract}

Keywords: Al-Andalus, Mozarabs, Architecture, Epigraphy, Archaeology

de referencia de estudio de las comunidades de cristianos andalusíes durante el siglo $X$ hasta la caída del califato-, en esta ocasión pretendemos revisar los otros documentos materiales y arqueológicos de estas comunidades. Nos referimos a los testimonios epigráficos y a la información conocida en la actualidad de las iglesias consideradas mozárabes, desde su concepción historiográfica y definición arquitectónica, sin olvidar su valor como documentos espaciales y permanentes de la existencia y pervivencia de los cristianos hispanos, con posterioridad a la conquista islámica de la Península, de su evolución y de su trazabilidad desde el punto de vista de los procesos productivos y de su capacidad de generary desarrollar un programa ornamental e identitario.

Un proceso generador de iglesias e instituciones religiosas, que podemos seguir a

\footnotetext{
* Artículo realizado dentro del proyecto: Relatos de intercambio Intercultural de conocimiento en la Edad Media y la temprana Edad Moderna (FFI2012-38606), del Ministerio de Economía y Competitividad (2013-2015).

** Museo Arqueológico de Alicante
} 
través de sus inscripciones fundacionales, cuyos alrededores acogieron cementerios de donde procede un amplio registro epigráfico que nos permite, con las reservas necesarias, adentrarnos en el conocimiento o en el perfil sociológico de estos cristianos, en su mayoría arabizados, que durante o bajo el califato decidieron legar su memoria en elaborados poemas tanáticos escritos en latín, a la vista de sus documentos epigráficos.

\section{Arte y Arquitectura cristiana: Mozá- rabe, de Repoblación, Fronteriza, de Fusión o de Resistencia}

Vicente Lampérez y Romea fue quien en el volumen primero de su obra "Historia de la Arquitectura Cristiana Española en la Edad Media", aparecida en 1908, estableció los criterios técnicos, en cuanto se refiere a los aparejos, materiales, etc, así como identificó los elementos constructivos y artísticos: arcos de herradura, bóvedas de cañón y de arista, ventanas, vanos, fachadas, etc. de la "Arquitectura Mozárabe", gracias a su formación como arquitecto y desde la arquitectura del monumento, aportando por primera vez plantas, secciones y alzados de las iglesias (Lámperez, 1908: 199-205).

Denominación de "Arquitectura Mozárabe" que venía a superar el tradicional concepto de "arquitectura romano-bizantina" utilizado por José Caveda en su Ensayo histórico de la Arquitectura Española (1848); seguido por arquitectos conocedores del arte islámico de la Península como el propio Ricardo Velázquez Bosco quien, en su discurso de constitución de la Comisión de Monumentos Históricos y Artísticos de la provincia de León, al referirse a la iglesia de San Miguel de la Escalada la definía como de "estilo latino-bizantino" (1866); o el propio José Amador de los Ríos -historiador y arqueólogo que fuera director fundacional del Museo Arqueológico Nacional-, que utilizaba esta denominación en los títulos de sus estudios sobre los monumentos cristianos tras la conquista islámica de Mérida (1877) y de Córdoba (AMADOR, AMADOR, 1879).
Resulta evidente que la utilización de este novedoso término por V. Lampérez y Romea, para referirse a la arquitectura religiosa de los cristianos no islamizados en la Península entre los siglos VIII y XI, está inspirada en su conocimiento de la "Historia de los Mozárabes" de F. J. Simonet aparecida en 1879 (1983), reiteradamente mencionada en su libro (LAMPÉREZ, 1908:110). Arquitectura mozárabe a la que consideraba como "... hijuela de la visigoda, sucesivamente degenerada y adicionada con ciertos elementos mahometanos.." (LAMPÉREZ, 1908: 195), a la vez que, siguiendo el ambiente del nacionalismo romántico de la época, la valoraba como una arquitectura genuinamente hispana que desapareció frente a la invasión de las influencias franco-germanas del Románico y del posterior Gótico:

"Al comenzar la Reconquista, los elementos latinos y bizantinos, unidos en la humilde degeneración del Arte Visigodo con algunos dejos mahometamos, dan forma á las modestas iglesias cantábricas y muzárabes. Lentamente adquieren unas y otras estilo propio. (...) Todo ello, desarrollado, hubiese formado un estilo nacional, pero acaece la invasión de reinas, condes y monjes franceses al final del siglo XI, y el estilo románico-español se trunca $y$, sobre sus restos, aparece el románico de la Auvernia, de la Aquitania y del Poitou" (Lampérez, 1908: 24)

Del conjunto de iglesias mozárabes y en atención a sus rasgos arquitectónicos, establece dos estilos o escuelas histórico-geográficas, aunque con matizaciones: la "Latina", conformada por las iglesias de Mérida y Toledo, aunque Melque la considera "Bizantina", y la propiamente "Bizantina", compuesta por las iglesias levantadas en tierras de León por los monjes huidos de Córdoba que portarían a la zona y según sus palabras "la tradición de las basilicas cordobesas, que no es otra que la visigoda..." y entre las que estarían las iglesias de San Miguel de Escalada y San Cebrián de Mazote (LAMPÉREZ, 1908:199). Según esta ordenación, y en primer lugar, describe en su obra las iglesias mozárabes existentes en el interior de al-Andalus, todas ellas con- 
centradas en Toledo: serían las iglesias de San Sebastián, Santa Eulalia, San Tirso, San Lucas y Santa María de Melque (LAMPÉREZ, 1908:210-218). A continuación, y fuera del territorio de al-Andalus, estudia y analiza aquellas a las que considera como "iglesias mozárabes en éxodo", en su mayoría en la provincia de León (LAMPÉREZ, 1908: 219-232): San Miguel de Escalada, San Cebrián de Mazote, -en el mismo valle que las iglesias de Bamba y San Román de Hornija en Valladolid (LAMPÉREZ, 1908: 240-242)-, Santiago de Peñalba y la de Santo Tomás de las Ollas (León), que fuera estudiada y dada a conocer por M. GómezMoreno (1907-8). Por último, las iglesias de San Miguel de Celanova (Orense), toda de sillería y con arco de herradura con arrabá (LAMPÉREZ, 1908: 233-235), de Santa María de Lebeña (Cantabria) (LAMPÉREZ, 1908:236-239), de San Millán de la Cogolla (Logroño) (LAMPÉREZ, 1908:243-248) y de San Baudelio de Berlanga (Soria) (LAMPÉREZ, 1908:249-252). A estas iglesias añadía un breve capítulo dedicado a los inexistentes, pero sí mencionados por las fuentes, monasterios mozárabes de la sierra de Córdoba, aunque utilizando como ejemplo, según su opinión, el alejado monasterio de San Juan de la Peña (Huesca) (Lampérez, 1908: 257-258). Edificios todos ellos y en su conjunto de una arquitectura "... humildísima de dimensiones, de elementos y de formas. Obra, en fin, exclusivamente popular (...) De aquíque el estudio de la Arquitectura Mozárabe es un campo reservado a nuestra arqueología nacional" (LAMPÉREZ, 1908: 195-6) (Fig. 1)

Quizás la manifestación de esta impresión o propuesta sirvió de estímulo para que, apenas unos años después, Manuel GómezMoreno escribiera su artículo intitulado "De Arqueología Mozárabe" (1913), germen de su posterior y más completa obra sobre las "Iglesias Mozárabes. Arte español de los siglos IX a XI", aparecida en 1919 y en la que confirmaba las bases de un programa constructivo y ornamental de un "Arte Mozárabe", nacional, diferente e identificador de la cultura de un colectivo compacto, formado por los primigenios cristianos no islamizados, instalados y dispersos por toda la geografía de la península Ibérica, y de un ámbito cronológico que

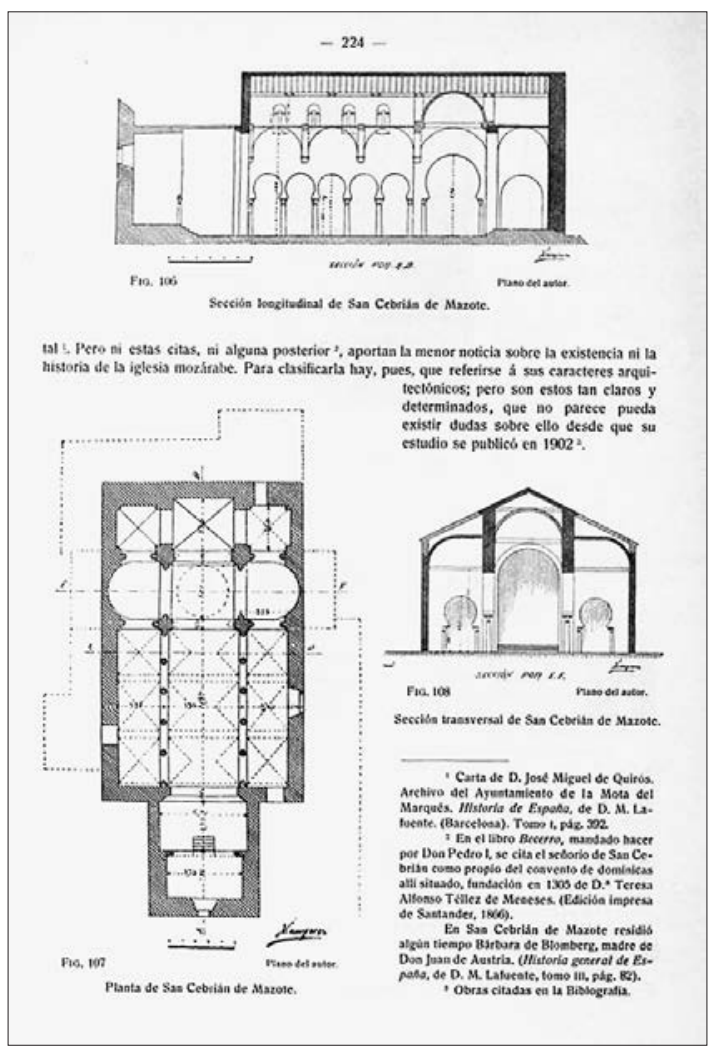

Fig. 1. Reproducción de la Planta y alzados de la iglesia de San Cebrián de Mazote, firmados por V. Lampérez y Romea que aparecen en la página 224 del volumen I de su obra "Historia de la Arquitectura Cristiana Española en la Edad Media” (1908)

según M. Gómez-Moreno se enmarcaría entre los años 850 y 1030, según la tabla de fechas fundacionales conocidas y aportada, coincidiendo con la construcción de la iglesia de San Juan de la Peña del 850, ampliada en el 928 , y la restauración llevada a cabo en el año 1030 de la iglesia de San Millán de la Cogolla, así como con la aparición por primera vez del término "mozárabe" en un documento del año 1024 (GÓMEZ-MORENO, 1919: XVII-XVIII)

Registro arquitectónico multiforme y ecléctico, como decía el propio M. Gómez-Moreno, desgajado "de nuestro arte godo, cordobés, prerrománico y morisco ..." (1919: IX) que procede de la agrupación de un importante número de iglesias extraídas en su mayor parte del capítulo que V. Lampérez y Romea dedicara a la "Arquitectura Mozárabe", ya mencionado, a las que añadiría algunas otras catalanas y aragonesas (GÓMEZ-MORENO, 1919: XXIII) extraídas de "L'Arquitectura Romá- 
nica a Catalunya", de J. Puig i Cadafalch, Antonio de Falguera y José Goday i Casals, aparecida ese mismo año de 1909. En base a estas obras compilatorias y a su criterio, hace un repaso de la arquitectura, que considera de los "mozárabes", por regiones y territorios de la Península. Comenzando por Andalucía, de la que dice no hay iglesias "mozárabes" porque fueron destruidas o no permitida su construcción por los musulmanes, como opinaba F. J. Simonet (GÓMEZ-MORENO, 1919: 5), por lo que en su mayoría se localizan en la España septentrional. De Toledo, desecha las iglesias de San Tirso, a la que considera una simple sala de un baño musulmán, de San Sebastián, Santa Eulalia y de San Lorenzo, -propuestas por V. Lámperez y Romea (1908:210-4)-, por considerarlas como moriscas (GÓMEZ-MORENO, 1919:12) y sólo reconoce a la iglesia de Santa Maria de Melque de Toledo (GÓMEZ-MORENO, 1919: 15-27). Del resto de los antiguos Reinos de León y Castilla mantiene prácticamente el mismo listado ya conocido, aportando como novedad, traída de la obra de J. Puig i Cadafalch et al (1909), las iglesias catalanas meridionales de San Miguel de Olérdola (Barcelona), de San Quirce de Pedret (Serchs, Barcelona), Santa María de Marquet (Pont de Vilomara i Rocafort, Barcelona) y de San Julian de Buada (Girona) (GÓMEZ-MORENO, 1919: 53-70). Del Reino de Asturias incorpora la iglesia de San Salvador de Valdediós, en donde encuentra almenas de tipo cordobés (GÓMEZ-MORENO, 1919: 76-81), y de Portugal, a la iglesia de San Pedro de Lourosa, cerca de Coimbra (GÓMEZMORENO, 1919:100-104).

Por último, en esta obra adelanta una secuencia del arte mozárabe, de tal manera que venía a decir: "Si en Andalucía y Toledo, como es probable, las iglesias eran basilicas, resulta natural que al mismo tipo obedezcan las primeras fundaciones mozárabes en León, a saber: Lourosa, Escalada, y Mazote; pero al contacto de otros tipos septentrionales, cruciformes y abovedados, o por la concurrencia de algún artífice oriental acaso, la estructura de las iglesias complicóse y progresivamente fueron surgiendo las de Melque, Bamba, Lebeña, Peñalba, Celanova, etc. (...) Separadamente, formóse otra derivación mozárabe la del arte del Califato hacia la parte oriental, del que poseemos dos ejemplares en San Millán y San Baudel, testimonios de la riqueza de soluciones posibles dentro de aquel arte, y que, por responder a una fase andaluza más avanzada, tienen ciertas conexiones con lo morisco posterior" (GÓMEZ-MORENO, 1919:XXI)

En resumen, un extenso corpus compuesto por una cuarentena de iglesias que se verá sustancialmente reducido en su posterior trabajo sobre el "Arte Mozárabe" aparecido en el volumen III del "Ars Hispaniae" (GÓMEZMORENO, 1951:353-412). Así, su listado de iglesias quedará reducido a veinte y una, de las cuales, 17 se perpetúan del primer elenco debido a V. Lampérez y Romea (1908), a las que añadirá las iglesias catalanas de San Miguel de Cuxá, en el Rosselló, y en Girona las de San Pedro de Roda y Santa Maria de Ripoll, en sus primeras fases arquitectónicas (GÓMEZMORENO, 1951: 363-369). Como importante novedad, hay que señalar la incorporación por primera vez en el interior de al-Andalus de una iglesia mozárabe, que será la rupestre de Bobastro de Málaga (GÓMEZ-MORENO, 1951: 365), descubrimiento arqueológico de principios de la década de los años veinte del siglo pasado, que fue dada a conocer por Cayetano de Mergelina $(1925,1927)$.

Selección de iglesias sin alterar por los trabajos de su alumno Leopoldo Torres Balbás quién, entre su larga y extensa producción científica, sólo dedicó dos artículos a determinados aspectos ornamentales del "Arte Mozárabe". Uno, en un apartado del publicado sobre "Los modillones de lóbulos. Ensayo de análisis de la evolución de una forma arquitectónica a través de diez y seis siglos" (Torres, 1936: 1-62) y el otro, mucho posterior, sobre "La pintura mural de las iglesias mozárabes" (TORRES, 1958: 417-424), en el que recogía la información sobre la pintura mural, -desconocida en su día por M. Gómez-Moreno-, gracias a una publicación de H. Schlunk y M. Berenguer sobre "La pintura mural asturiana de los siglos IX-X” (1957), y en el que aportaba como novedad la decoración pictórica de la iglesia de Santiago de Peñalba (León), cuyas 
pinturas fueron publicadas un año antes por el arquitecto, José Menéndez Pidal (1956).

La obra de M. Gómez-Moreno tuvo una indiscutible repercusión entre los hispanistas franceses. Así H. Terrasse en su obra "L'Art Hispano-Mauresque des origines au XIIIe siècle" le dedica unas páginas, reconociendo la influencia del arte omeya sobre las iglesias de los cristianos levantadas en las tierras reocupadas (TERRASSE, 1932); pocos años después, Élie Lambert escribía un artículo dedicado a "La Civilisation Mozárabe", en el que recogía aquellas iglesias más representativas, en las que veía claras influencias presentes en ciertos monumentos prerrománicos del sur de Francia (LAMBERT, 1939). Han de transcurrir varios decenios hasta la publicación en Francia, y al año siguiente en España, de la obra "L'Art Préroman Hispanique.II. L'Art Mozarabe" de Jaques Fontaine, alumno de M. Gómez-Moreno, el cual renovará y defenderá la vigencia del discurso de su maestro (1978)

Por el contrario, desde los círculos de investigadores españoles del Arte y la Arquitectura Prerrománica fueron puestas en duda, con matices, las tesis de M. Gómez-Moreno. De tal manera que ya J. Camón Aznar, atendiendo a la geografía de las "iglesias mozárabes", concentradas en su mayoría en las tierras de la expansión del Reino Leonés, venía a proponer el considerarlas, en línea con la opinión de H. Terrasse, no como "iglesias mozárabes" sino como una "arquitectura de repoblación" (1963). Propuesta que fue recogida con agrado por I. Bango (1974). Más aún, J. M. Pita Andrade, ante la específica geografía de estas obras, venía a matizar o calificar a esta "arquitectura de repoblación" como un "arte fronterizo", siguiendo la estela, muy de moda en la época, de los "poemas o romances fronterizos" de la Reconquista (PITA, 1975:103-135). Posteriormente, I. Bango fue más allá y sin abandonar los criterios cronológicos y espaciales, trasladaba la cuestión a sus aspectos sociológicos, proponiendo el considerar restrictivamente al "arte mozárabe" como una manifestación de las "comunidades cristianas de resistencia" en el interior del territorio o bajo el dominio islámico de al-Andalus (BANGO, 2001:214-5). De esta escuela es A. M. Martínez Tejera, a quién debemos una revisión actual de este debate historiográfico, viniendo a sugerir, por tanto, el nuevo término para estos edificios religiosos de la zona de León o de la "España Libre" no islamizada, como "Arquitectura de Fusión” (MARTínEZ, 2011, 2016).

Debate terminológico y de implantación territorial, según el cual la denominación de arquitectura "mozárabe" sólo sería aplicable a aquellas iglesias levantadas por los cristianos durante el dominio islámico y en el territorio interior de al-Andalus. Por otro lado, las iglesias conservadas en los reinos cristianos presentan plantas, elementos y ornamentos muy diferentes que sitúan la discusión en la probable existencia de diversas escuelas o arquitecturas mozárabes, como así lo confirmaba el posterior y riguroso estudio de los "capiteles mozárabes" efectuado por S. Noack-Haley (1990), entre los que establecía la siguiente clasificación crono-tipológica: siendo los de la primera fase los capiteles de las iglesias de San Salvador de Valdediós (Asturias, 893); San Cebrián de Mazote (915-6); monasterio de Sahagún ( 935); y la iglesia de la Hornija, todos ellos en la Tierra de Campos; los de la segunda fase serían los capiteles del Monasterio de San Miguel de Escalada (912) y del Monasterio de San Pedro de Eslonza (912), en la diócesis de León. Un tercer grupo estaría formado por las iglesias de Lebeña (Cantabria) (930); Santiago de Peñalba en el Bierzo y Santa María de Bamba (Valladolid) de una cronología del tercer y cuarto decenio del siglo X. Por último, y a partir del ecuador del siglo X, se constata el comienzo de la desaparición de los capiteles y su dispersión hasta su desaparición (NoackHaley, 1990: 41-2). Capiteles mozárabes de iglesias y monasterios procedentes en su mayor parte de la zona Astur-Leonesa, de una cronología limitada a la primera mitad del siglo X, con posterioridad al 912 (Cressier, 1991:171), cuyo vacío y ausencia en las tierras meridionales de la Península nos lleva a plantearnos si existió una arquitectura de los mozárabes en el interior de al-Andalus. 


\section{II. ¿Hubo una arquitectura mozárabe en al-Andalus?}

La respuesta parcial a esta pregunta la encontramos en el reciente artículo debido a Luis Caballero y Ma de los Ángeles Utrero quienes, al analizar el "El ciclo constructivo en la Alta Edad Media Hispánica (Siglos VIII-X)" (2013: 129-131), actualizan la revisión crítica efectuada por el mismo Luis Caballero de la arquitectura cristiana posterior al 711 (CABALLERO, 2001; 2011) y la exhaustiva revisión realizada por Ma Ángeles Utrero (2006), confirmando que, en contra de las disposiciones prohibitorias islámicas (SIMONET, 1983:443444), hasta mediados del siglo IX, fueron contadas las iglesias cristianas que se construyeron, pervivieron o se reformaron en el territorio de al-Andalus (CABALLERO, 2000: 226-7): siendo claros ejemplos las iglesias compartidas con mezquitas de Córdoba (MARFIL, 2000) o la reconstrucción de la iglesia de Aranas en S. Joâo de Azinhais (Alcacer do Sal, Portugal), según atestigua su lápida fundacional del año 882?, (Real, 1998: 38); así como las iglesias de perduración de los complejos monásticos de Santa Lucía del Trampal (Alcuéscar, Cáceres) (CABALLERO, SÁEZ, 1999) y de Santa María de Melque (Toledo) (CABALLERO, 2000; 2006, 2011; 2013). Sin embargo, no es menos cierto que todas ellas fueron destruidas o abandonadas coincidiendo con la fitna, a finales del siglo IX (CABALLERO, 2000: 234).

Abandono o amortización generalizada de iglesias (AILLET, 2010: 45ss) que perfectamente se ha documentado en la ciudad de Mérida (MATEOS, ALBA, 2011; CABALLERO, UTRERO, 2013: 129), en la misma Córdoba (MARFIL, 2000), confirmado tras la revisión de sus necrópolis (SÁNCHEZ, 2007) y restos arqueológicos de época visigoda (SÁNCHEZ, 2006) o en Toledo, en donde el complejo áulico visigodo de la Vega Baja, -que albergaría la basílica martirial de Santa Leocadia y la basílica de los Santos Apóstoles Pedro y Pablo, en donde se celebrarían los concilios-, fue abandonado a mediados del siglo IX (IZQUIERDO, 2009; 2011). Proceso perfectamente constatado en las tierras orientales de la península Ibérica, como serían los casos de la basílica de Eio o del Tolmo de Minateda (Hellín, Albacete), desacralizada a principios del siglo IX, tras la fundación de la ciudad de Murcia en el 825 (GUTIÉRREZ, ABAD, GAMO, 2005; GUTIÉRREZ, 2011; AMORÓS, CAÑAVATE, 2010). En la misma Valencia, gracias a la arqueología (RIBERA, ROSSELLÓ, 2011) conocemos perfectamente el proceso de abandono del complejo basilical visigodo, amortizado a finales del siglo VIII (RIBERA, 2005), así como el de la cárcel - Mausoleo de San Vicente convertido en unos baños árabes en el siglo X (SORIANO et al 1998). Por último, haremos referencia al palacio visigótico o villa áulica del Pla de Nadal (Ribaroja, Valencia), destruido a finales del siglo VIII (JUAN, LERMA, 2000; CABALLERO, UTRERO, 2013: 129; RIBERA, coord. 2015).

Datos arqueológicos que no pretenden ser exhaustivos, sino representativos de un panorama en el que se confirma la desaparición o amortización, a mediados o finales del siglo IX, de la mayoría de los edificios civiles y de las antiguas iglesias o monasterios cristianos levantados en el territorio de al-Andalus en el siglo VIII (CABALLERO, UTRERO, 2013); algunos de los cuales fueron además arabizados, como sucede en los casos de las basílicas de Casa de Herrera (Mérida) (ULBERT, 1991) y de Milreu (Estói) (Portugal) (SIDARUS, TEICHNER, 1997) o en la iglesia de Almonaster la Real (Huelva), en las cuales se ha documentado la presencia de grafitos árabes, realizados tras el abandono o desacralización de las basílicas cristianas y cuando todavía estaban en pie o no habían sido destruidas, y cuyo estudio denota que estamos ante la prueba de una evidente arabización de los colectivos cristianos, pues las inscripciones responden a fórmulas características de los nuevos conversos, posiblemente detenidos por no pagar impuestos y encerrados en estos edificios, utilizados muy probablemente como cárceles o prisiones temporales (BARCELÓ, 2001, 2002), en contra de la opinión de Manuel L. Real que las considera como espacios eclesiásticos en uso en ese momento (2014:257). Claras muestras de que estas comunidades rurales de cristianos ya estaban en un proceso de arabización e islamización a finales de siglo IX (BARCELÓ, 2001: 116) 
En conclusión y a la vista de los datos arqueológicos, nos preguntamos: ¿Cuáles serían, o si hubieron, las iglesias levantadas por los cristianos arabizados, pero no islamizados, durante los siglos IX y X en al-Andalus?. Para responder a esta pregunta debemos seguir a Fernando Arce cuando consideraba que el único ejemplo conservado de arquitectura de los "mozárabes" sería la iglesia rupestre existente en el yacimiento de Bobastro (ARCE, 2000:87). Nos referimos a la iglesia del complejo monástico excavada parcialmente en la roca de las Mesas de Villaverde, en Ardales (Málaga), descubierta en la década de los años veinte del siglo pasado y dada a conocer como ejemplo de "arquitectura mozárabe" por Cayetano de Mergelina $(1925,1927)$ y datada a comienzos del siglo X, en concreto en el 917 (PUERTAS, 1979). Tesis que se ha visto reforzada con la aparición y excavación de otra iglesia en el mismo yacimiento de Bobastro, pero en la parte superior de su alcazaba, de la que sólo se conserva la impronta de su planta y es similar: de tipo basilical de tres naves, con triple cabecera absidial (MARTíNEZ, 2004; 2012:147183). Planta muy parecida a las de las iglesias castellano-leonesas de San Cebrián de Mazote y de San Miguel de Escalada, como se aprecia en su estudio comparativo, que además son de similar cronología, 913-916, y levantadas, como sabemos, por "mozárabes provenientes de Córdoba” (MERGELINA, 1925, 1927; Puertas, 1999-2000), aunque las fuentes sólo hacen referencia a monjes venidos con un "Abad" procedente de "Hispania" (AILLET, 2010:255-6). Iglesias de Bobastro, levantadas por los cristianos andalusíes no islamizados, de origen Hafsuní, es decir del 912-928 (ACIÉN, 1994: 117), como sabemos por los textos (ACIÉN, 2009) (Fig. 2)

Iglesias que desde el mero análisis tipológico efectuado por R. Puertas Tricas, -en el que las englobaba en el grupo VIII o de las iglesias de tres naves con ábside de herradura (19992000: 143, fig. 38)-, o desde la nueva concepción "mozarabista" de los "ciclos productivos", -caracterizada por la innovación debida a la aparición de talleres y grupos con nuevas aportaciones técnicas no continuistas-, se corresponden perfectamente con el grupo de "iglesias con transepto y cubierta de madera. Finales del siglo IX, primer cuarto del siglo $X$. Bobastro en territorio andalusí, Lourousa en portugués, Escalada y Mazote en leonés y Pravia en Asturiano", planteado por L. Caballero y Ma de los Ángeles Utrero (2013: 128)

Lo cierto es que estas iglesias de planta basilical o latina, apenas constituyen un reducido grupo dentro de la diversidad tipológica de las iglesias mozárabes que planteaba M. Gómez-Moreno (1919), así como lo es en la clasificación en siete ciclos productivos dentro de la arquitectura cristiana de la Alta Edad Media Hispana establecida por L. Caballero y Ma de los Ángeles Utrero (2013). Nos encontramos ante unas iglesias, documentadas arqueológicamente en Bobastro, cuyos prototipos se alejan de los edificios "visigotistas" de la Península, y se acercan a prototipos que parecen provenir de las iglesias bizantinas de Mallorca y de Menorca, como pusiera de manifiesto R. Puertas Tricas (1979: 202) y
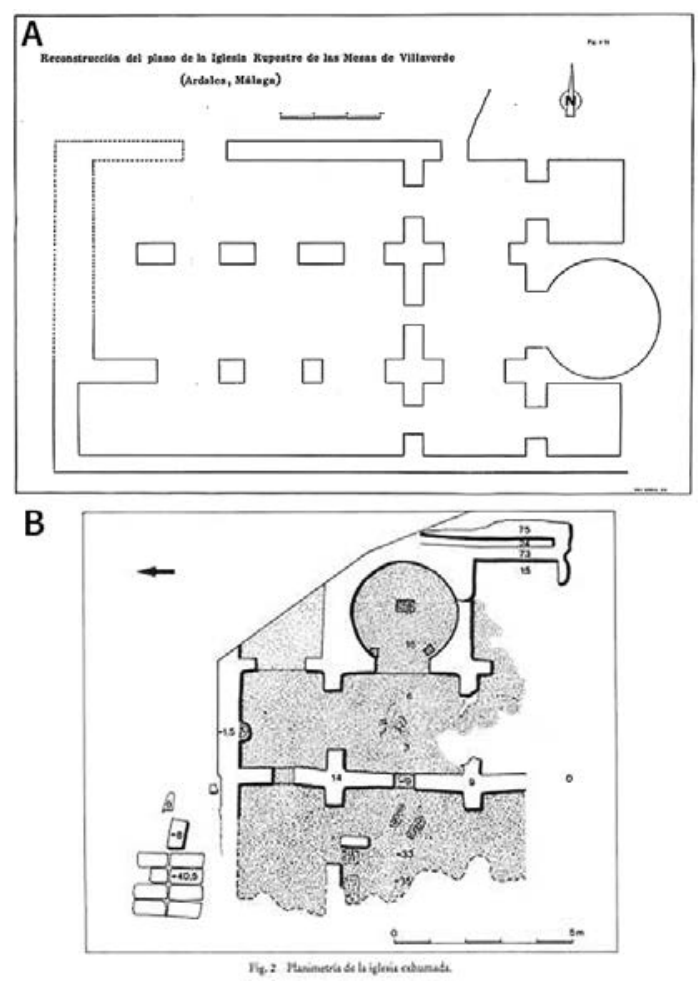

Fig. 2. Plantas de las iglesias mozárabes de Mesas de Villaverde (Ardales, Málaga). A) iglesia rupestre de Bobastro (Puertas, 1979: 194) y B) planta de la del interior de la alcazaba (Martínez, 2004: 509, fig. 2) 
ha revisado V. Martínez Enamorado (2004: 516-7), que a la vez tienen sus paralelos en las iglesias rupestres de tres naves de Ronda (PUERTAS, 1987; 1999-2000), enlazando así con los conjuntos eremíticos malagueños de Coín y Archidona (PUERTAS, 1986; 1999-2000), considerados en su día como de los siglos IX-X (PUERTAS, 1989).

En conclusión, la arqueología nos confirma que, a finales del IX y en el interior del territorio de al-Andalus, apenas quedaban restos de aquella arquitectura religiosa de los dimmíes desarrollada acogiéndose a los "Pactos" o desde la "resistencia", en opinión de A.M. Martínez Tejera (2003), de tal forma que habían desaparecido o amortizado las iglesias o complejos basilicales de las antiguas ciudades o sedes episcopales visigodas; así como estaban abandonadas las iglesias de perduración o de reconstrucción de los incipientes monasterios cristianos, centros de producción campesina en el ámbito rural, como serían los casos de Santa María del Trampal (Alcuéscar, Cáceres) o de Melque en Toledo, o los no descubiertos monasterios de la serranía de Córdoba (CASTEJón, 1949; PÉREZ, 2012: 185-190), como sucede con los de Tábanos y Peñamelaria (ARCE, 1992); y en algunos casos las antiguas iglesias o basílicas cristianas, aún en pie, fueron arabizadas, muestra clara de su desacralización, como serían los casos de Casa de Herrera, Milreu o Almonaster la Real. Ausencia de iglesias en el interior de al-Andalus en el siglo X que coincide con la inexplicable falta de inscripciones conmemorativas mozárabes, como veremos a continuación, frente a las conocidas de las fundaciones septentrionales de las iglesias de San Miguel de la Escalada (913), de San Pedro de Montes(919) (MARTíNEZ TEJERA, 1996), San Martín de Castañeda (921), San Cosme y San Damián de Abellar (921) en la que se menciona al abad cordobés Martino, y la de San Cebrián de Mazote (916), entre otras (GONZÁLEZ, 2002:743).

En este generalizado panorama de ausencia de restos de arquitectura religiosa cristiana en al-Andalus, sorprende el que las únicas manifestaciones constructivas de una arquitectura de los llamados "mozárabes", o cristianos no islamizados, sean la de los restos de las iglesias de Bobastro, en Mesas de Villaverde, levantadas por Ibn Hafsun, tras su bautismo y conversión, y destruidas en el 928 (ACIÉN, 1994). Iglesias cuya arquitectura y planta podrían ser ejemplo y perduración de aquellas, no conservadas, de planta basilical cordobesa, al decir de V. Lampérez y Romea (1908: 199), que a la vez portaron los cristianos Hispani que acompañaron al abad Alfonso, en su huída al reino de León, y rehicieron o levantaron la iglesia de San Miguel de Escalada (León) en el primer cuarto del siglo X, entre otras (MARTíNEZ, 1996)

Arquitectura que, por otra parte, está asociada formalmente a los eremitorios rupestres de las sierras de Málaga, desde Ronda hasta Archidona, como manifestaciones físicas o fruto del proceso de generación y creación espontánea, a lo largo del siglo X, de colectivos o grupos minoritarios y marginales de cristianos andalusíes, no islamizados, a los que podemos considerar como asimilados por el régimen, pero que sin duda no podemos definir como "rebeldes" al califato, ya que no conocemos, -a diferencia de lo que sucedió a finales del siglo IX con las revueltas muladíes, siendo la más famosa la encabezada por Ibn Hafsun (ACIÉN, 1994; MARTíNEZ ENAMORADO, 2012)-, ninguna noticia documental sobre levantamientos de estas comunidades en el interior de al-Andalus a lo largo del siglo X.

\section{Inscriptiones Christianae en al-Andalus}

Cronología tardía o del siglo X para las manifestaciones arquitectónicas de los cristianos no islamizados, ya sea en el interior o en la frontera septentrional de al-Andalus, que coincide, en parte, con la aportada por el registro epigráfico latino altomedieval conocido hasta la actualidad. Así, en el primer corpus de inscripciones cristianas en latín elaborado a finales del siglo XIX por A. Hübner (1871) encontramos que de las inscripciones no 210 a la 288, ambas inclusive, correspondientes a las lápidas fechadas entre los años 778 y 1051 , es decir entre los siglos VIII al XI, sólo o apenas 
17 proceden de los territorios del interior de al-Andalus. Listado ampliado por el mismo A. Hübner en su "Suplementum", aparecido en al año 1900, en el que de los números 453 a 464 , incorporó doce nuevas para un período ampliado hasta el siglo XII, haciendo un total de 27 epígrafes, de las consideradas de escritura "mozárabe", para un período extendido de los siglos IX al XII d.C.

Aquel primer registro exhaustivo se ha ido completando a lo largo del siglo XX, siendo fundamental el trabajo posterior de recopilación de restos materiales atribuibles a los "mozárabes", y en concreto a sus documentos epigráficos, que efectuara Manuel Gómez-Moreno, ampliando el anterior registro de inscripciones de A. Hübner $(1871,1900)$ incorporando cinco nuevas (GÓMEZ-MORENO, 1919: 364-369). Catálogo apenas incrementado posteriormente, con contados ejemplares correspondientes al grupo de lápidas procedentes del territorio granadino: una muy sencilla en la que sólo consta el nombre de "Recosindo" que se encontró en Quéntar en 1919 y proviene de la colección M. Gómez-Moreno, depositada en el Museo Arqueológico Provincial de Granada (MAP. 1867) (PASTOR, 2002: 89-90, no 60), al igual que otra más elaborada, la lápida del Abad Recosindo, de fines del siglo $X$, aparecida en el Atarfe en el año 1959 (MAP. 8594) (PASTOR, 2002: 81-2, no 53). A estas hay que añadir las recibidas en el Museo de Málaga (SERRANO, ATENCIA, 1981) procedentes de la antigua colección Villaceballos (RODRÍGUEZ, 2003); las depositadas en el Museo Arqueológico Nacional (FRANCO, 1992: 79-81) y las tres inéditas, pertenecientes a colecciones privadas, una del año 906 y otra bilingüe del 998, dadas a conocer por J. González (2002) y por último, una fragmentada, y también bilingüe, considerada como de fines del siglo $X$, principios del siglo XI, que está en estudio por parte de $\mathrm{M}^{\mathrm{a}}$ Antonia Martínez (2014: 65, fig. 9). Sorprende el que no existan, o no hayan aparecido hasta el momento, inscripciones latinas posteriores al siglo VIII ni en Cáceres (ESTEBAN, SALAS, 2003), ni en Mérida (RAMÍREZ, MATEOS, 2000), aunque está comprobada la existencia de un barrio "mozárabe" en la zona del antiguo monasterio para hombres o Xenodochium, o albergue para peregrinos, a las afueras y al norte de la ciudad romana y cercana a la basílica de Sta. Eulalia abandonada en el siglo IX (RAMÍREZ, MATEOS, 2000: 280-1). Por otro lado, es muy interesante el cimacio visigodo procedente de Mérida, utilizado como base de una inscripción en latín y en hebreo, correspondiente a la lápida sepulcral del Rabí Jacob, hijo del Rabí Senior, de una cronología de fines del siglo IX (ALMAGRO, 1976: 136, Lám. LIX, a y b; RAMÍREZ, MATEOS, 2000: 245-8, no 197; VIDAL, 2011). Ante este panorama, no muy alentador, hay que añadir que está todavía pendiente por conocerse la epigrafía latina post-visigoda de Toledo y resulta difícil de explicar la ausencia de inscripciones en la Sevilla Metropolitana (GONZÁLEZ, 2002: 749)

Con estos datos hemos elaborado la siguiente tabla de las inscripciones latino-cristianas procedentes del interior de al-Andalus y de los siglos IX al XI d.C., en concreto entre los años 850-1010, partiendo del catálogo de inscripciones de A. Hübner (IHC) (1871, 1900), completándose en otro color con aquellas piezas relacionadas por M. Gómez-Moreno (MGM) (1919) y con las inscripciones descubiertas hasta hoy en día y publicitadas, lo que hace un total de 38, algo menos de las 52 que constituyen la totalidad del corpus, contabilizando las de los siglos VIII, XII y XIII (GONZÁLEZ, 2002). En la primera columna se indica el año, en la segunda el número de referencia del corpus de A. Hübner o de inventario de las inscripciones depositadas en museos y, por último, la procedencia de la inscripción y la indicación del personaje que aparece (Fig. 3).

Lo primero que salta a la vista de la tabla de registros epigráficos latinos encontrados en el interior de al-Andalus es su avanzada o tardía cronología, ya que la más antigua sería la inscripción procedente de Trévelez (Granada), depositada en el Museo de la Alhambra con no inv. 002871, de una imprecisa cronología de los años 852-886 (Hübner, 1900:100, no 454, Gómez-Moreno, 1919: 365, fig. 200; Pastor, 2002: 90-1, no 61, fig. 41). De esa cronología de la segunda mitad del siglo IX son además seis lápidas procedentes: tres de Córdoba y tres de Granada. Las primeras corresponden 


\begin{tabular}{|c|c|c|}
\hline Año & Número & Lugar. Personaje \\
\hline $852-886$ & IHC 454 /MA002871 & Trévelez. Granada. Diácono Floresindo \\
\hline 868 & IHC 218 & Córdoba. S. Eulogio) \\
\hline 890 & IHC 219 & Córdoba. Archipresbitero Cypriano \\
\hline IX? & MAN 50060 & Granada. Domenicus \\
\hline Fines S. IX & IHC 375/MAP 10016 & La Zubia. Granada \\
\hline Fines S. X? & IHC 132/MM CE05261 & Córdoba. Obispo? Teudefredo \\
\hline 906 & Inédita(Sevilla) & Córdoba. Basilisa \\
\hline 923 & IHC 220 & Córdoba. Cenobio de san Pauli (Marmolejos) \\
\hline 925 & IHC 455 /MR.Torres & Córdoba. Iohannes Eximius \\
\hline 927 y966 & IHC 222/ Malcazaba? & Córdoba. Epitafio de monja Tranquila y madre Spaciosa \\
\hline 930 & MGM & Adamuz (Córdoba). Abad Daniel \\
\hline 931 & IHC 223 & Córdoba. Monasterio de S. Martin \\
\hline 931 & IHC 460 & Sin lugar. Atana? \\
\hline 936 & MGM & Córdoba. Monja Killio \\
\hline 948 & MGM & Córdoba. Monja lusta \\
\hline 955 & IHC 221 & Córdoba. Campana de Abad Samsó \\
\hline 958 & IHC 214 & Málaga. Comares. Presbítero Samuel \\
\hline $962 ?$ & IHC 224 & Córdoba. Eremitorio S.Ma Villa Viciosa. Epitafio Cisclus \\
\hline $962-3 ?$ & IHC 225 & Córdoba. Epitafio del niño Matheus \\
\hline 977 & MGM & Córdoba. Rufina \\
\hline 981 & IHC 461 & Córdoba. Epitafio incierto Presbítero \\
\hline 982 & IHC 464 & Córdoba. Epitafio de Salvato \\
\hline $982 ?$ & MAN 62295 & Córdoba. Elisabeth \\
\hline $984 ?$ & IHC 215 & Antequera. Málaga. Monje Amansuindo \\
\hline 984 & MS ROD2637 & Córdoba. Crismatis \\
\hline $984 ?$ & MAN 57847 & Córdoba. Epitafio anciana Paula \\
\hline $982 / 7 ?$ & IHC 226 & Córdoba. Epitafio esposa de "Sarraceni" \\
\hline 987 & IHC 228 & Córdoba.Epitafio de Abeatarecus ."Hijo de Tariq" \\
\hline $986-991 / 987$ & IHC 210 & Tavira/Faro (Portugal). Iuliani Opiscopi \\
\hline $993 ?$ & IHC 227 & Córdoba. Episcopus \\
\hline 998 & inédita & Córdoba. Palma del Rio. Juan. Lápida bilingüe \\
\hline 1000 & IHC 213 & Badajoz. Episcopo Daniel \\
\hline 1002 & IHC 216 & Jotrón. Málaga \\
\hline 1002 & IHC 456 /CE00228 & Elvira.Granada. Noble Cipriano \\
\hline Fines S.X & MAP 8594 & Atarfe. Granada. Abad Recosindo \\
\hline Fines S. X-XI & MAP 1867 & Quéntar. Granada. Recosindo \\
\hline Fines S.X-XI & IHC 457/MAP 1228-9 & Mesas de Villaverde. Málaga \\
\hline Fines S.X-XI & Inédita & Córdoba. Ibrahim. Lápida bilingüe \\
\hline
\end{tabular}

Fig. 3. Tabla cronológica de las inscripciones mozárabes encontradas en el interior de al-Andalus, de mediados del siglo IX al 1010 d.C.

a los números 218 y 219 del catálogo de A. Hübner (1871:71-2) de los años 868 y 890, y la conocida como lápida de Lucena, depositada en el Museo de Málaga (no Inv. CE05261) (LEVIPROVENÇAL, 1987: 119, fig.. 14), correspondiente al epitafio de Teudefredo, considerada por
A. Hübner como de una amplia cronología de los siglos VIII-X (1891, n 132), aunque procedía de las excavaciones efectuadas a fines del siglo XIX para la estación del ferrocarril de Córdoba y que a través de la colección Villaceballos pasó al museo de Málaga (RODRÍGUEZ, 2003:356; 
MARTÍNEZ NÚÑEZ, 2014:64). De Granada procede la mencionada de Trévelez, la no 454 del Suplementum (HÜBNER, 1900) y las dos restantes, una depositada en el Museo Arqueológico Nacional (no inv. 50060) y la otra, la procedente de La Zubia, depositada en el Museo Arqueológico de Granada (MAP 10016). No portan cronología y se han catalogado genéricamente como de fines del siglo IX. Exceptuando estas seis lápidas, el resto, treinta y dos inscripciones, son todas del siglo X. De la primera mitad del siglo, partiendo del año 906, se conocen nueve inscripciones, todas ellas procedentes de Córdoba. Por último, de la segunda mitad del siglo X hasta el año 1002, son la mayoría y suponen un total de 23 inscripciones de las que prácticamente la mitad se fechan en las dos últimas décadas del siglo, coincidiendo con el gobierno de Almanzor. De todas ellas sólo se conservan en museos algo más de una decena de inscripciones y esperemos que en un futuro las tres inscripciones publicadas, que todavía están en manos privadas, pasen a conservarse en museos o instituciones públicas. En resumen, datos que podemos analizar en la siguiente gráfica (Fig. 4)

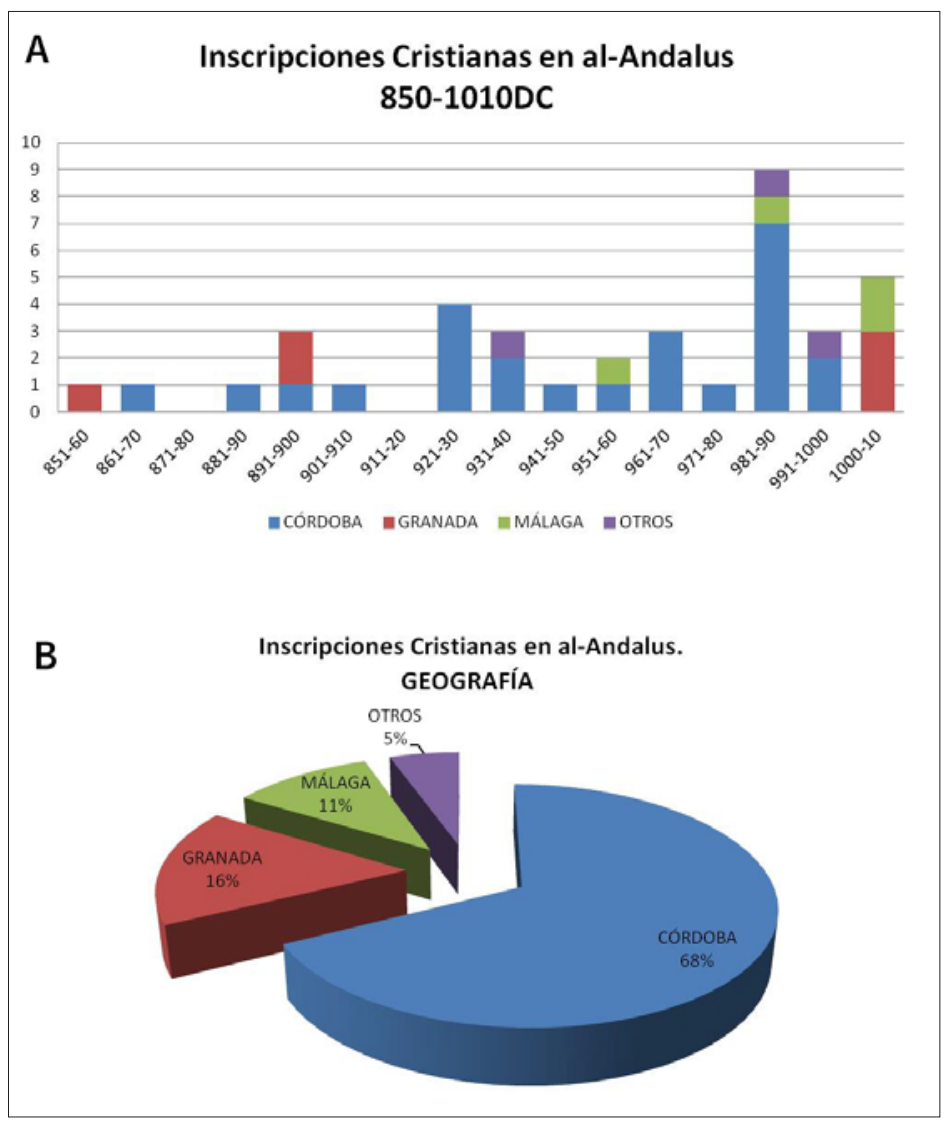

Como vemos, unos documentos epigráficos latinos que se circunscriben en su mayor parte a la época del califato y sobre todo a la segunda mitad del siglo X, como ya había puesto de manifiesto J. González (2002: 749). Otro aspecto a destacar es la geografía de estos documentos epigráficos. Según la gráfica que hemos construido en base a la ubicación o procedencia de las inscripciones, se aprecia para la segunda mitad del siglo IX dos núcleos claros de procedencia de estas lápidas: tres son de Córdoba y las otras tres de Granada: la más antigua de Trévelez (852-886) y las otras dos de fines del siglo IX procedentes de la Vega del Genil, una conservada en el Museo Arqueológico Nacional no 50060 (FRANCO, 1992: 79-81; VIDAL, 2011: 262-3) y la otra es una placa de barro cocido procedente de La Zubia (MAP, no 10016) (GÓMEZ-MORENO, 1919:369; PASTOR, 2002: 92, fig. 42). Cuando llegamos al siglo $X$, las inscripciones se concentran en su mayor parte en Córdoba, de donde proceden nada menos que 22 lápidas, de una cronología que se extiende desde el año 906 al 993. Geografía epicéntrica que, a partir de los años ochenta del siglo, se dispersa y desplaza hacia el sur, en una amplio espacio definido por los hallazgos en Granada y en Málaga. Las de Granada se localizan en las poblaciones de la Vega del Genil, de Quéntar (PASTOR, 2002: 89, fig. 40) y en el Atarfe, de donde proceden dos lápidas (PASTOR, 2002: 81-3, fig. 33 y 34) y una de ellas encontrada en la misma ciudad de Medina Elvira, la del noble Cipriano, del año 1002, que ya publicara M. Gómez Moreno-González (1888: 192). Las de Málaga son también tres, una del año 982?, y las otras dos proceden de la

Fig. 4. Gráficas de las inscripciones cristianas de al-Andalus de fines del siglo IX al 1010d.C. A) Evolución cronológica y producción, B) Geografía de aparición en Córdoba, Granada, Málaga y otros. 
serranía, una de Jotrón, del 1002, y la otra de la propia Mesas de Villaverde, de fines del siglo X, principios del siglo XI, conservada en el Museo Arqueológico y Etnográfico de Granada (MAP no 1228-9) (GÓMEZ-MORENO, 1919: 195; PASTOR, 2002: 286, fig. 179 a-b). Por último, y casi de forma presencial, conocemos las lápidas de los Obispos, Daniel de Badajoz, del año 1000, y de Juliano, cuya inscripción se conoce como la de Tavira (HÜBNER, 1871: 69, no 210) aunque se encontró en Caçela Velha (Faro) (REAL, 2014: 276-7) y se conserva en Évora (Portugal), de una cronología algo anterior, del 987 d.C., según la lectura revisada de Ma Antonia Martínez (2014: 64-5).

Una geografía de inscripciones funerarias del siglo X que confirma la concentración de la comunidad o comunidades cristianas no islamizadas en Córdoba, como ya había puesto de relieve J. González (2002: 749), con un origen coincidente con la instauración del califato y que irá decayendo al final del mismo. Epicentrismo del cristianismo cordobés que tiene unos orígenes en el último tercio del siglo anterior, de donde proceden tres lápidas de cronología posterior a los sucesos de los mártires de Córdoba. Por el contrario y durante el califato, las comunidades del área granadina desaparecerán sin dejar rastro epigráfico hasta un siglo después, cuando a fines del siglo X volvemos a encontrar tres lápidas, siendo la más conocida la mencionada del noble Cipriano, procedente de Medina Elvira del año 1002 (Fig. 5).

Tras el hiato de los veinte primeros años del siglo X, en el que sólo se conoce una inscripción, - la publicada de la virtuosa "Basilisa" (GONZÁLEZ, 2002: 746, Lám. II)-, constatamos un evidente vacío epigráfico debido, muy posiblemente, o como consecuencia del aplastamiento de la sublevación muladí llevada a cabo por el futuro califa 'Abd al-Raḥmãn III. Por el contrario y como reacción a la represión, y en atención a los registros epigráficos, se observa la emergencia de una comunidad cristiana, no islamizada, que conserva o se manifiesta por primera vez en "latín", identificada y concentrada en la propia Córdoba. Concentración geográfica que, en base a la cifra de inscripciones, alcanzará su cenit bajo el gobierno de Almanzor, a la vez que comenzará a disgregarse a finales del siglo X, constatándose la diáspora de comunidades de cristianos, según la geografía de las inscripciones, hacia Granada, Málaga, y de muy baja intensidad, con apenas una sola lápida, hacia Badajoz y Tavira/Faro en el Algarve (Portugal).

Inscripciones, además, que son todas ellas funerarias, desconociéndose alguna de carácter conmemorativo o fundacional, hasta el momento, lo que confirmaría el abandono o la ausencia de construcciones de iglesias como se ha visto. Por otro lado, sus contenidos nos permiten adentrarnos en el conocimiento de estas comunidades y de sus individuos. Así, aunque la opinión generalizada es que la mayoría de las lápidas hacen referencia a personajes de extracción social alta, ya sean

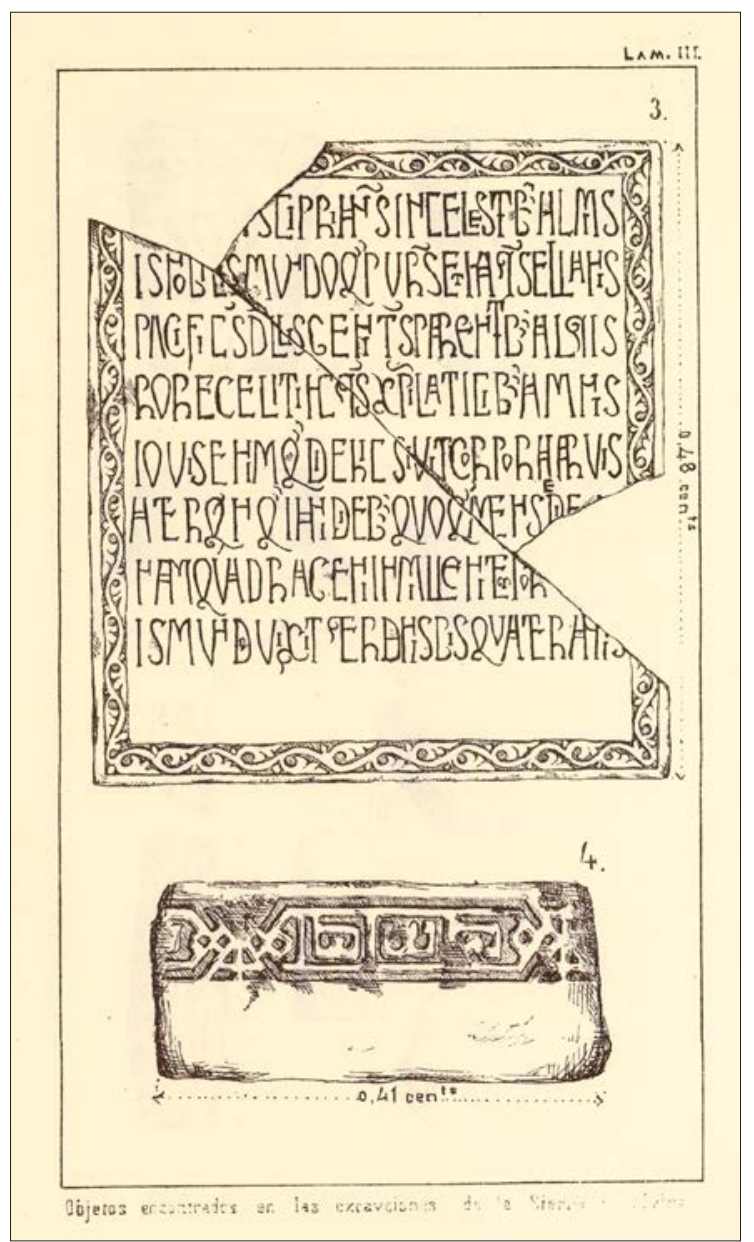

Fig. 5. Lápida del Noble Cipriano, del año 1002d.C, encontrada en Medina Elvira, según calco de M. Gómez Moreno Martínez (1888: 92 ) 
pertenecientes a la jerarquía eclesiástica o a la aristocracia (ACIÉN, 2009; MARTÍNEZ NÚÑEZ, 2014); si realizamos una revisión más detallada de las mismas, se observa que son contadas las inscripciones que hacen referencia a cargos eclesiásticos, de tal forma que de Córdoba sólo conocemos la del Archipresbítero Cypriano, del año 890 y a finales del siglo X, la de un Presbítero de Córdoba del año 981 y la de un dudoso Obispo de Córdoba del año 962?, copiada por A. Hübner de la obra del siglo XVII de Bernardo Gamiz de Cabrera (1871: 75, n²27) pero no recogida en la relación posterior de M. Gómez-Moreno (1919), ni en ninguna otra. Como vemos, de dos decenas de lápidas procedentes de Córdoba no hay ni una sola que haga referencia o corresponda a algún Obispo, siendo el cargo más alto el del Archipresbítero Cypriano, o Arcipreste catedralicio nombrado por un Obispo. Fuera de Córdoba, sólo se conocen las del Obispo Juliano (987) y la del Obispo Daniel de Badajoz del año 1000. en el occidente de al-Andalus.

Por el contrario, los textos epigráficos sí que confirman una importante e intensa vida monástica de estos cristianos, a lo largo del siglo X y bajo el califato de Córdoba. Así conocemos las lápidas del Abad Daniel de Córdoba (930), del fraile Martinus, obispo de Écija (Sevilla), del año 931, que se retiró al cenobio de "Rojana" de la sierra cordobesa (GÓMEZ-MORENO, 1919:366; SERRANO, ATENCIA, 1981: 56-7, n० 59; RIESCO, 1988: 199-204 n’3; RODRÍGUEZ, 2003:356); las lápidas de las monjas Killio y lusta, de los años 936 y 948, procedentes del desaparecido monasterio de Santa Eulalia de Córdoba (NAVAL, 1914), junto con la de la monja-abadesa Rufina (977d.C.), dada a conocer por el padre F. Fita (1914: 557-8), como las recoge M. Gómez-Moreno (1919:367); la de la monja Tranquila, muerta en el año 927 en un monasterio de Córdoba (Serrano, Atencia, 1981: 58, no 62, lám. LXXXV; Riesco, 1988: 197-8, no 2; Rodríguez, 2003: 356) (Fig. 6), así como de las lápidas de la mártir Eugenia, encontrada en el cenobio de San Pablo, y la de Cisclus (962?), hallada en el eremitorio de Santa Maria de Villa Viciosa de Córdoba (HÜBNER, 1871: 72 y 74, no 220 y 224). Datos que de por sí nos sugieren que estos cristianos de Córdoba, en atención a sus documentos epigráficos, estaban vinculados a la vida eremítica organizada o no en comunidades monásticas, ya sean de hombres o de mujeres, y dispersos por su serranía, en donde se encontrarían, entre otros, los monasterios no descubiertos, aunque sí estudiados, de Tábanos y Peñamelaria (Arce, 1992). Los rasgos de estas comunidades de cristianos reducidos a la vida eremítica y monacal se constatan también fuera de Córdoba. Así, entre las lápidas procedentes de Málaga encontramos la del monje Amansuindo del año 982? , hallada en los montes de Málaga, y la del Abad Recosindo, procedente del Atarfe granadino y de finales del siglo $X$.

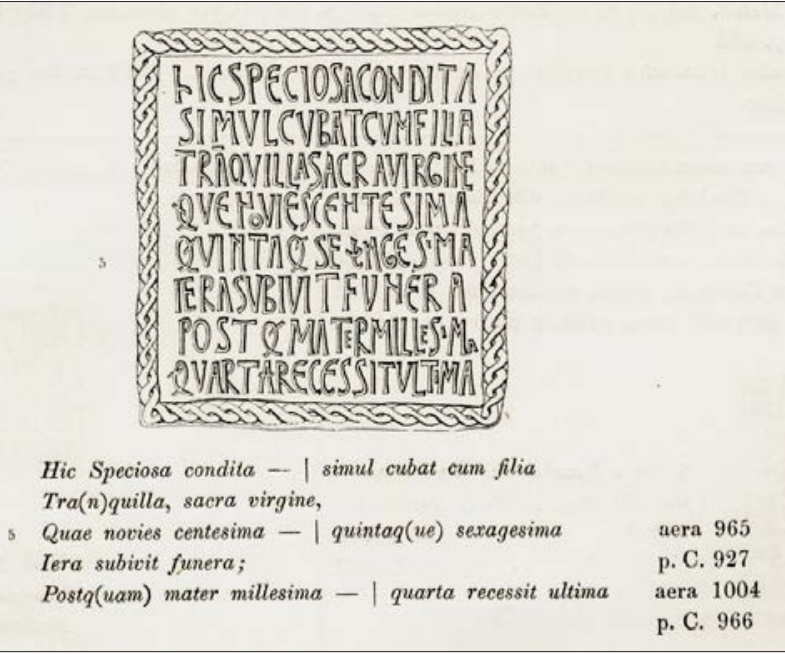

Fig. 6. Dedicatoria de Spaciosa a su hija, la monja Tranquila, según calco de A. Hübner (1871: 73, IHC 222)

En conclusión, la documentación epigráfica latina confirma la cronología tardía de aparición de estos cristianos no asimilados, en el interior de al-Andalus y bajo dominio islámico, con unos orígenes en el último tercio del siglo IX y en una geografía dispersa entre Córdoba y Granada. Será a finales del siglo X cuando se manifestarán de forma intensa y concentrados en los alrededores de Córdoba. Cristianos o comunidades desplazadas de la urbe y del área palatina cordobesa, y recluidos en monasterios dedicados a la vida eremítica 
que conformarían lo que se ha dado en llamar el "cristianismo oculto" o las comunidades de "cripto-cristianos" (AILLET, 2010: 314). Comunidades de vida monacal y eremítica, totalmente apartadas del poder y de la jerarquía eclesiástica, que en los años finales del siglo $X$, coincidiendo con el gobierno de Almanzor, y en atención a la documentación epigráfica, parece que se van a retirar de Córdoba y a emigrar a las serranías de Granada y de Málaga, así como al Algarbe, momento en el que se expresarán, por primera vez, en su doble condición de cristianos y arabizados, a la vista de los recientes hallazgos de las dos lápidas bilingües cordobesas: la encontrada en las proximidades de Palma del Río, del año 998 (GONZÁLEZ, 2002: 743, n¹) y el fragmento de lápida procedente de la misma Córdoba, de finales del siglo X (MARTíNEZ NÚÑEZ, 2014: 65, Fig. 9).

\section{Arquitectura y epigrafía de los mozárabes de al-Andalus}

La conquista de la península Ibérica se llevó a cabo por un numeroso ejército compuesto por beréberes de diversas tribus, dominados por una minoría conquistadora de árabes que, a base de Pactos de Capitulación o Rendición con las oligarquías dominantes hispanogodas (CHALMETA, 2003), consiguieron establecer su dominio sobre una población mayoritariamente cristiana o cristianizada, asentada en las ciudades y organizada territorialmente según la antigua administración eclesiástica. En algunos de estos pactos se establecía el respeto a la religión cristiana y a sus iglesias, como en el caso del conservado Pacto de Teodomiro del año 713, en el que se dice lo siguiente: "No serán obligados [a renunciar] a su religión, incendiadas sus iglesias ni despojadas de sus objetos de culto" (CHALMETA, 2003: 208) siempre que cumplan con sus obligaciones fiscales impuestas en su condición de dimmî o protegidos del Islam.

Estos pactos permitieron que en un principio no fueran destruidas las iglesias paleocristianas o visigodas. Pero lo que la arqueología nos confirma es que a finales del siglo IX, y en el interior del territorio de al-Andalus, habían desaparecido o amortizado las iglesias o complejos basilicales (CABALLERO, 2011) de las antiguas ciudades o sedes episcopales visigodas como Toledo, Mérida, Córdoba, Valencia, etc; así como estaban abandonadas las iglesias de perduración o de reconstrucción de los incipientes monasterios cristianos, centros de producción campesina en el ámbito rural, como serían el de Santa María del Trampal (Alcuescar, Cáceres) (CABALLERO, SÁEZ, 1999) o el de Melque en Toledo (CABALLERO, 2000, 2006), o el no descubierto monasterio de Tábanos en la serranía de Córdoba (ARCE, 2000). En algunos casos, las antiguas iglesias o basílicas cristianas, aún en pie, fueron arabizadas, muestra clara de su desacralización, como serían los casos de Casa de Herrera, de Milreu o de Almonaster la Real (BARCELÓ, 2001, 2002). Proceso progresivo de abandono de las antiguas iglesias y de los nuevos complejos monásticos de explotación agrícola (AILLET, 2010: 45ss) que debió iniciarse tras la pérdida de los derechos de los primigenios "Pactos de Capitulación", y del aumento de la presión fiscal ejercida por 'Abd al-Rahmãn II, tras sus reformas, culminando con Muhammad I (8524) y su prohibición de construir nuevas iglesias (MOLINA, 1983: 160, no 50), siguiendo muy probablemente las leyes promulgadas por el califato 'Abbasí, aunque muy probablemente de dudosa efectividad (MARTínEZ TEJERA, 2003: 53-6).

Datos arqueológicos de abandono de iglesias y de su posterior desacralización o arabización, así como de las explotaciones monásticas, que confirman, en parte, la rápida islamización de la antigua población hispano-cristiana dimmî o muladí, así como de su progresiva arabización, si nos atenemos a los estudios recientes (AILLET, 2010; MANZANO, 2006: 326-7), lo que explicaría, en cierto modo, la quiebra constatada de las inscripciones paleocristianas a partir del siglo VIII y la ausencia o desaparición de testimonios epigráficos en latín hasta mediados del siglo IX (HÜBNER, 1871, 1900; PASTOR, 2002). Será a partir de mediados del siglo IX y en concreto tras la lápida procedente de Trévelez, en la Alpujarra granadina, de imprecisos años entre 
el 852 y el 886, cuando nos encontremos con el primer testimonio arqueológico en escritura mozárabe, nunca mejor dicho, de la existencia de cristianos no asimilados en el interior de al-Andalus.

Ciertamente, como ya analizamos en el capítulo anterior y según las gráficas de la figura 4, se aprecia como el incipiente proceso de generación de inscripciones de cristianos, -que se entierran y utilizan el latín mozárabe en sus lápidas-, arranca tímidamente a finales del siglo IX, con apenas cinco lápidas en cincuenta años, repartidas entre Córdoba y Granada, para pasar a un período de vacío que se produjo entre los años 900 y 928, seguramente debido a la represión ejercida sobre los "muladíes" tras la fitna de fines del siglo IX (ACIÉN, 1994, 2009). Con la instauración del califato asistiremos a un fuerte resurgir del número de inscripciones, con una evidente concentración en Córdoba, que se mantendrá hasta los años finales del siglo X. Coincidiendo con la llegada del califa Hishâm II y bajo el gobierno de los Amiríes es cuando se asiste a una muy probable diáspora de las comunidades cristianas instaladas en Córdoba, las cuales se retirarán, según los registros epigráficos y como se ha visto, hacía las serranías de Granada y Málaga, o hacia las zonas más alejadas al suroeste de la capital, es decir a los territorios de pervivencia de las antiguas comunidades cristinas en Extremadura y el Algarve (REAL, 2014).

Esta dinámica geo-histórica es interesante compararla con la gráfica que muestran las inscripciones cristianas documentadas en los territorios septentrionales de la Península, libres del dominio islámico de al-Andalus en esta misma época. La comparación plasmada en una nueva, -confeccionada para ser com- parativa con los datos del corpus epigráfico de A. Hübner (1871, 1900)-, es de gran interés porque ayuda a entender de una forma más global la dinámica de estas comunidades de cristianos en el territorio de la Península, a caballo entre los siglos IX y X. Así, se aprecia como ante el débil registro de inscripciones documentado en el interior de al-Andalus en la segunda mitad del siglo IX, nos encontramos con una evidente mayor presencia en los territorios cristianos: de las cinco conocidas del interior de al-Andalus, pasamos a cuadruplicar esta cifra con un registro que asciende a 18 inscripciones procedentes de los reinos cristianos y concentradas entre los años 871 y el 920, para desaparecer, significativamente, con la instauración del Califato de Córdoba en el 928-9 (Fig. 7).

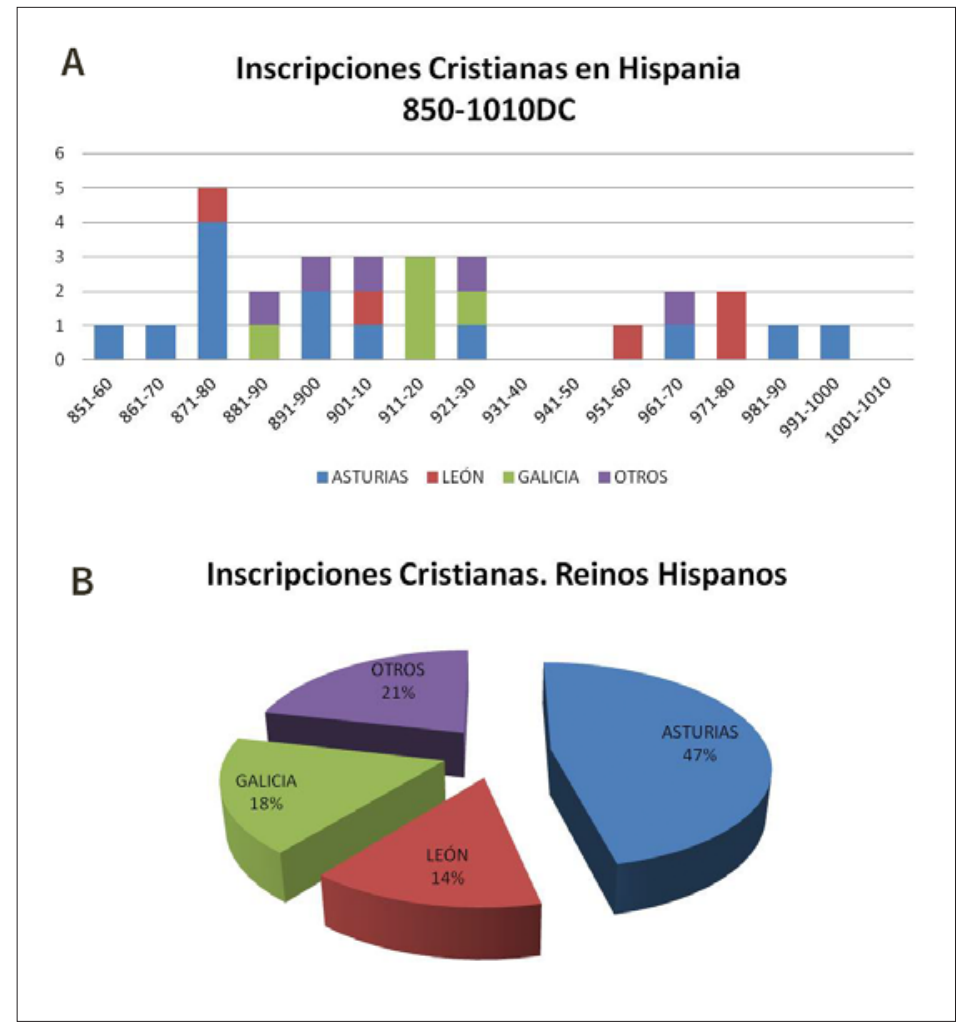

Fig. 7. Gráficas de las inscripciones cristianas de Hispania, de fines del siglo IX al 1010d.C. A)Evolución cronológica y producción, B) Geografía de aparición en los Reinos de Asturias, León, Galicia y otros. 
IX y la instauración del Califato de Córdoba. Así, en la secuencia epigráfica se aprecia como la primera lápida o inscripción latina de la que se tiene constancia, después de la conquista islámica de la Península, sigue siendo hasta ahora la incompleta inscripción encontrada en la localidad de Trévelez (Granada), ya mencionada, referente al Diácono Floresindo que fue enterrado durante el reinado de "Mohammet", rey de los sarracenos ("Reg[em] / [Mo]h(a)mmet re/gem sarracenor(um)", es decir bajo el gobierno del emir Muhammad I, entre los años 852886. Primer documento epigráfico que abre una exigua serie de inscripciones fehacientes de la existencia material y por primera vez de estos cristianos no asimilados en al-Andalus y de cronología posterior al conocido suceso de los mártires de Córdoba (MANZANO, 2006: 336341). Episodio desencadenante de la escisión abierta entre la iglesia oficial, instalada en el poder y encargada de controlar la tributación territorial de los dimmî para el estado islámico (ACIÉN, 2009), y aquellos incipientes y reducidos grupos de dimmî o muladíes que no estaban conformes con las cargas tributarias impuestas por el Emir de Córdoba. Malestar generalizado entre la población mayoritariamente muladí que estallará en las revueltas de finales del siglo IX (MANZANO, 2006:341ss), siendo la más virulenta la dirigida por Ibn Hafsún, en la serranía de Málaga (ACIÉN, 1994; 2009; MARTÍNEZ ENAMORADO, 2003, 2012) quién llegó a bautizarse cristiano y levantó los dos únicos monumentos o iglesias que podemos considerar como mozárabes o de los cristianos andalusíes, nos referimos a las mencionadas iglesias de Bobastro en Mesas de Villaverde (MARTÍNEZ, 2004), destruidas en el año 928, tras ser sofocadas estas revueltas por el califa 'Abd al-Raḥmãn III.

Los efectos de esta represión y persecución llevada a cabo por el futuro califa se hará notar en el incremento o aumento de la emigración de colectivos y grupos de cristianos que se produjo en esos años, de fines del siglo IX y principios del $\mathrm{X}$, -a la vista del desmesurado número de lápidas e inscripciones documentadas en los reinos cristianos-, que se instalarán en la periferia de al-Andalus, en las tierras de la frontera, sobre todo en las del naciente reino de León, en donde los documentos escritos atestiguan la llegada de monjes procedentes de Córdoba o de Hispania, a los que se encomendó la fundación de monasterios o iglesias como las de San Miguel de Escalada y de San Cebrián de Mazote entre los años 912-3 (GÓMEZ-MORENO, 1919), dejando constancia en un importante número de lápidas fundacionales de iglesias, entre los años 906-921 (GONZÁLEZ, 2002: 743; MARTíNEZ TEJERA, 1996, 2003, 2016)

Esta constatada diáspora de cristianos del interior de al-Andalus hacia las tierras de la frontera del Duero, huyendo de la dura represión llevada a cabo por el futuro califa 'Abd al-Raḥmãn III a principios del siglo $X$, se completa con la materialización de la ruptura entre la iglesia oficial y los antiguos "muladíes" andalusíes, dando lugar a la formación de nuevas comunidades de cristianos, contrarios a su asimilación y perfectamente rastreables por sus inscripciones funerarias. Cristianos que se van a concentrar, a la vista de sus registros epigráficos, en comunidades religiosas, principalmente, en los alrededores de Córdoba, la ciudad palatina del califato andalusí, y en la presumible importante comunidad cristiana granadina de Medina Elvira. Comunidades de cristianos sin relación o vinculación alguna y sin una identidad cohesionada (MANZANO, 2006:328-9; ACIÉN, 2009; AILLET, 2010), dedicados o retirados a la vida cenobítica en eremitorios o monasterios alejados de la ciudad y dispersos por la serranía de Córdoba. Será a finales del siglo $X$, coincidiendo con los últimos años del califato de Córdoba y bajo el gobierno de los Amiríes, cuando se constata una emigración o diáspora de estos cristianos de Córdoba hacia el sur, a la enriscada Alpujarra granadina o a la serranía de Málaga, en donde y según las inscripciones, seguirán desarrollando aquella vida eremítica y muy probablemente en las iglesias o monasterios rupestres documentados en Ronda o en Antequera, confirmando los rasgos ya descritos del "cristianismo oculto" de al-Andalus (AILLET, 2010:314). La coincidencia entre la concentración de inscripciones de esta época y la zona en donde se encuentran estas iglesias rupestres, nos permite sugerir 
como hipótesis el que estas iglesias rupestres podrían ser de fines del siglo $X$ y no del siglo IX, en contra de la opinión aceptada de forma general (PUERTAS, 1989; 1999-2000; MARTíNEZ ENAMORADO, 2003: 162ss)

\section{De la cultura material de los cristianos andalusíes en el siglo $\mathrm{X}$}

Con el fin de identificar a estas comunidades de cristianos desde un análisis arqueológico, secuencial y comparativo, hemos confeccionado el siguiente cuadro cronológico de la cultura material de las comunidades cristianas no islamizadas en la península Ibérica entre los años 850 y el 1030. En la tabla hemos recogido prácticamente todos los restos arqueológicos y documentales considerados en un momento determinado como "mozárabes", ya sean iglesias, inscripciones, códices u objetos suntuarios vinculados al ritual cristiano, -siguiendo la propuesta que hiciera M. Gómez-Moreno (1919)-, agrupados según procedan o hayan sido elaborados en el interior de al-Andalus o en el territorio de los reinos cristianos. Así también, en la selección de las iglesias hemos seguido la efectuada por S. Noack, en base a la presencia de elementos decorativos indubitables del "arte mozárabe" (1990). Con el fin de no ser exhaustivos en el detalle de las inscripciones, las hemos agrupado en regiones 0 territorios históricos según su procedencia geográfica y, por último, hemos incorporado las dataciones conocidas y constatadas de los objetos suntuarios y de los códices, con el fin de confeccionar una tabla geográficocronológica de la dinámica de aparición y evolución de los restos arqueológicos o materiales de aquellas comunidades cristianas no islamizadas bajo el califato andalusí en territorio peninsular (Fig. 8).

Lo primero que salta a la vista es la dicotomía cronológica y geográfica que reflejan los registros arqueológicos y materiales, de tal forman que podemos afirmar que la instauración del califato de Córdoba por 'Abd al-Rahmãn III en el año 928-9, supondrá un punto de inflexión importante en el devenir de las comunidades de cristianos no islamizados, ya sean en el territorio interior de al-Andalus o en el de los reinos cristianos del norte. Así, se aprecia como la llegada e instalación de estos cristianos procedentes de al-Andalus, - a los que las fuentes latinas de la época denominan Hispani o venidos de Spania (AILLET, 2010:255)-, se va a producir, según los testimonios epigráficos, entre los años 890 y 930, coincidiendo o a consecuencia de la fitna y la posterior represión ejercida por el futuro califa contra los seguidores de Ibn Hafsûn (ACIÉN, 1994; MARTíNEZ ENAMORADO, 2012), que culminaron con las campañas de recuperación de Badajoz y Toledo, llevadas a cabo a finales de la década de los años veinte del siglo X (LEVI-PROVENÇAL, 1987:275-7).

A este marco cronológico hay que añadir el geográfico, de tal forma que con los datos de la tabla, -a los que hemos añadido los recopilados en su día por J. L. Corral de las iglesias y elementos constructivos y artísticos considerados como "mozárabes" (Corral, 1981)-, hemos elaborado un mapa en el que se aprecia perfectamente como la geografía de la cultura material denominada "mozárabe" se enmarca, cuantitativamente y de forma general, en la frontera entre al-Andalus y los reinos cristianos, extendiéndose desde los montes de León a los Pirineos orientales, ocupando la franja que conforman las tierras del piedemonte meridional de la cordillera Cantábrica y de los Pirineos, hasta la cuenca del río Llobregat; pero no de una forma homogénea y extensiva, sino claramente concentrada en determinados núcleos o áreas.

Áreas o territorios que, del occidente al oriente, responden también a una clara evolución cronológica difusionista. Así, los núcleos de primera repoblación de cristianos emigrados de al-Andalus, según la cronología epigráfica de construcción de iglesias o monasterios, se localizan o concentran en los recién creados reinos de Galicia y León, coincidiendo con la muerte de Alfonso III el Magno en el año 910, quién repartió sus reinos entre sus hijos Ordoño y García. Tras la muerte de éste último en el 914, Ordoño II se convirtió en rey de Galicia y León, en donde se localizan las 


\section{. Iglesias}

-S. Román de Hornija (Valladolid)

- Valdediós (Oviedo)

-S. Miguel de Escalada (León)

-S. Cebrián de Mazote (Valladolid)

-Rivas do Sil (Orense)

- S. Martin de Castañeda (Zamora)

-Sahagún (León)

-Santa Ma Bamba (Valladolid)

-Santiago de Peñalba (León)

-San Pedro de Eslonza (León)

-San Millán (Rioja)

-San Quirze (Girona)

\section{Epigrafia}

-Oviedo (Astur)

-Orense-Pont. (Gallaica)

-Barcelona

- Jaca

-Bilbao-Álava

-León

\section{Artes Suntuarias}

-Cruz de la Victoria (Oviedo)

- Cruz de plata (Oviedo)

-Arca Santa (Oviedo)

- Ara de plata (Oviedo)

- Cruz de Peñalba (León)

-Relicario de Celanova(Orense)

\section{Códices}

- Libro de Tattilano (León)

-Beato Magio (León)

-Biblia de la Catedral (León)

-Beato de Tábara (León y Urgell)

-Códice Albeldense (La Rioja)

-Códice Emilianense (La Rioja)

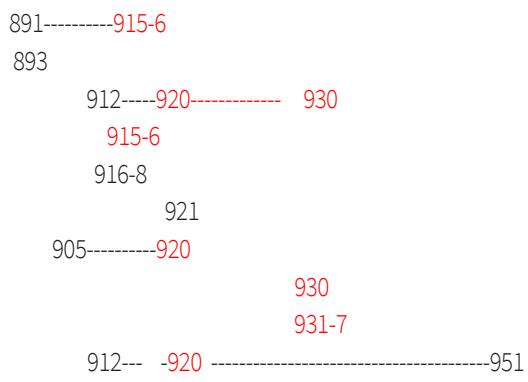

984

983
874

\begin{tabular}{|c|c|}
\hline 89390 & 910 \\
\hline 890 & 912 \\
\hline 890 & 914 \\
\hline 901 & \\
\hline 893 & \\
\hline
\end{tabular}

894906

878

874

$900 ?$

910

940
910 926

883

929
925
928

962

993

AL-ANDALUS $\quad$ 'Abd al-Raḥmān III Al-Hakam II 1926 Hixam II

1. Iglesias

-El Trempal (Cáceres)

-Melque (Toledo)

-Eremitorios (Málaga)

-Bobastro (Málaga)

917

$--928$

2. Epigrafía

\section{- Córdoba}

-Granada

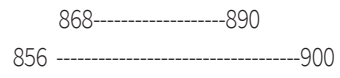

923--------936

949

962

970-975

976

Málaga

958

-Tavira (Portugal)

99

-Badajoz

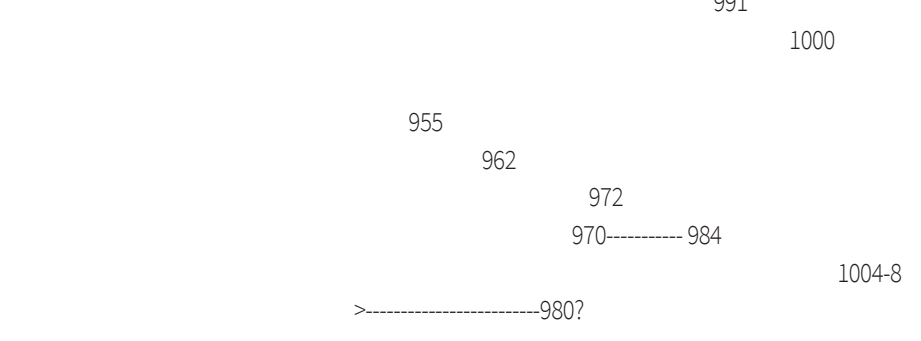

3. Artes Suntuarias

- Campana de Abad Samsó (Córdoba)

-Candil Salomonis

-Aguamanil (Louvre)

-Cruz -Ara de San Millán

- Cáliz de Braga (Portugal)

-astrolabio Destombes

902

-Códice Trasamundo (Toledo)

-Cod. Abadesa Gundissa (Toledo)

- Florencio (Córdoba)

938

-Biblia Hispalense (Sevilla)

Fig. 8. Tabla cronológica comparativa de la cultura material de los cristianos en la península Ibérica. Segunda mitad del siglo IX al 1010d.C. 
iglesias leonesas de San Miguel de Escalada y de San Pedro de Eslonza, levantadas en los años 912-3, así como San Cebrián de Mazote (916-8) o el Monasterio de Rivas do Sil (Orense) de esos mismos años.

Proceso constructivo que se irá extendiendo y propagándose hacia el sur, sobre el mismo cauce del Duero, en la década de los treinta con las iglesias de Hornija y Santa Maria de Wamba, y hacia levante, en la cuenca del Llobregat, donde encontramos el grupo formado entre otras por las iglesias de Sant Juliá de Boada (Girona) (934), Santa María de Marquet (956) y de San Quirce de Pedret (983) (FONTAINE, 1978: 285-303), en los antiguos condados catalanes de Urgel y Berga que pasaron a depender del unificado condado de Barcelona, a fines del siglo $X$, bajo el conde Borrel II (940-992). En el centro de estos territorios extremos se encuentran San Millán de la Cogolla, fundado tardíamente en el 984 y San Baudelio de Berlanga en Soria, cuya construcción podría considerarse como del segundo tercio del siglo XI (ALONSO et al, 1997; ZOZAYA, 1976, 2003). (Fig. 9A)

Una crono-geografía de lo "mozárabe" en tierras cristianas con claros orígenes en los límites del naciente Reino de León, tras la fundación de su capital en el año 910, que se extiende desde Sahagún, pasando por San Miguel de Escalada y San Martin de Castañeda, hasta Orense (MARTÍNEZ TEJERA, 2003, 2016) y las tierras portuguesas de Braga al Duero, de fuerte presencia "mozárabe" (AILLET, 2009, 2010; REAL, 2014), coincidiendo con la geografía de los antropónimos y topónimos árabes de esta zona (FERNÁNDEZ, 2009; MARTÍNEZ, 2011). Cuyos más claros ejemplos serían las mencionadas tempranas iglesias de San Miguel de Escalada y San Martin de Castañeda, construidas o reconstruidas por monjes venidos de Córdoba entre los años 912-916, años en los que también se levantan San Pedro de Arlanza y San Cebrián de Mazote, etc. Geografía de construcción que coincide plenamente con la aportada por las inscripciones, las cuales en su mayoría y las más antiguas hacen referencia o están vinculadas al devenir del Reino de Asturias, ya que se concentran en los valles asturianos y cantábricos, entre los años 874 y
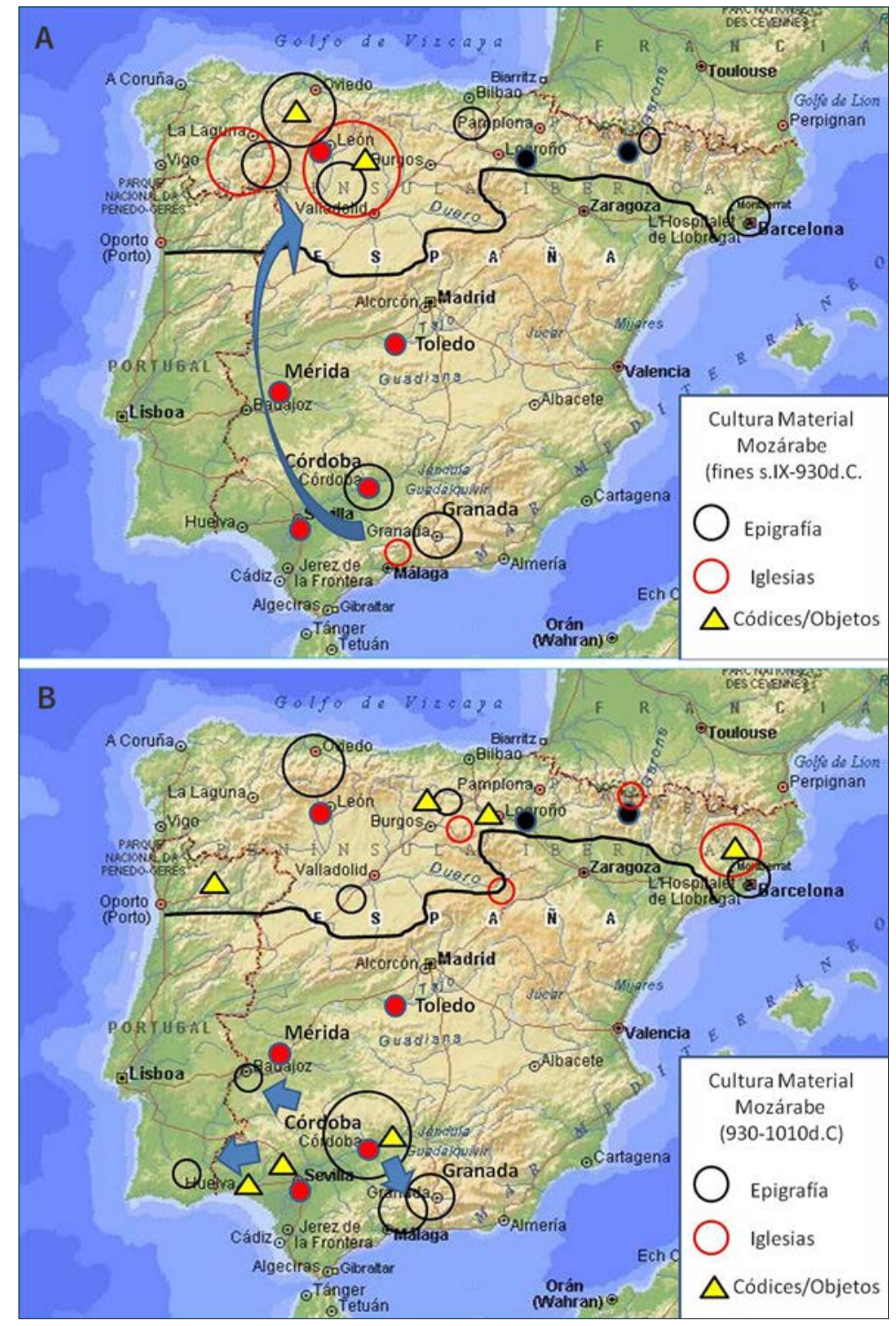

Fig. 9. Mapa geográfico de la cultura material de los cristianos andalusíes en la Península Ibérica. A) de Fines del siglo IX al 930 d.C.; B) del 930 al 1010 d.C. 
910, período que coincide con la cronología de la mayoría de las reliquias o tesoros del Arte Asturiano, conservados en la Cámara Santa de la catedral de Oviedo, como serían la Cruz de la Victoria del 874, el Arca Santa y Ara de plata de entre los años 900-910. A éstas más antiguas, le siguen en número de inscripciones, las procedentes de la zona de Orense-Pontevedra, de una cronología entre los años 890 y el 925, y las de León de los años 894 y 906, diferenciadas cronológicamente de las anteriores y separadas geográficamente por los montes cántabros, ya que los nuevos asentamientos cristianos se producirán en sus estribaciones meridionales y en los territorios de repoblación del naciente reino de León-Galicia. Documentos epigráficos que coinciden con la crono-geografía de las lápidas fundacionales de varias de las nuevas iglesias prerrománicas, pero no de arte asturiano, sino de clara influencia islámica o andalusí, ya mencionadas, y cuyo último eslabón lo constituirá la iglesia de Santiago de Peñalba de León, datada en el 937 (MARTíNEZ TEJERA, 2003; 2016). Ámbito cronológico y geográfico coincidente, también, con el de los códices mozárabes, así se comprueba cómo se circunscriben al ámbito Leonés, de donde proceden el Libro de Tattilano del año 910 y la Biblia de la catedral de León, del año 920, al igual que el Beato de Magio que se escribió, precisamente, en el scriptorium de San Miguel de Escalada a partir del 926 (GÓMEZMORENO, 1919: 361; AILLET, 2010: 164-166).

Una primera mitad del siglo $X$ marcada por el asentamiento de cristianos, venidos de al-Andalus, en las tierras del recién creado Reino de León, en donde serán capaces de levantar o reconstruir un conjunto de iglesias prerrománicas, sin vinculación con el arte Asturiano, y con un programa decorativo propio, marcadamente rupturista e influido por los parámetros de la arquitectura y el arte islámico califal (CABALLERO, 2011; MARTíNEZ TEJERA, 2016). Rasgos artísticos presentes también en sus Códices y en los Beatos, lo que en conjunto y por su identidad geográfica se ha denominado a este arte de los cristianos emigrados de al-Andalus como "Arte Fronterizo", de "Repoblación" o de "Fusión" (CAMÓN, 1963; PITA, 1975; MARTÍNEZ TEJERA, 2011)
Por el contrario, y a la vista de la tabla, la dinámica de las comunidades de cristianos que permanecieron en el interior al-Andalus es totalmente contraria y muy diferente, según los registros arqueológicos. Así, se aprecia una ausencia generalizada de documentos materiales de los mismos en la primera mitad de la tabla, desde finales del siglo IX hasta la instauración del califato, y por el contrario una profusión de registros o testimonios arqueológicos durante el califato hasta finales del siglo $X$, a diferencia de la ausencia de los mismos en los reinos cristianos. Es como si estas comunidades de cristianos en al-Andalus se visualizaran arqueológicamente bajo el califato y no antes. Más bien, constatamos como a finales del siglo IX van desapareciendo las antiguas iglesias o monasterios como los de El Trampal (Alcuéscar, Cáceres) o de Melque (Toledo) (CABALLERO, 2010, 2011; ARCE, 2010) y sólo se conoce la fundación de las iglesias de Bobastro, levantadas en el año 917 y abandonadas y destruidas en el año 928 (MARTíNEZ ENAMORADO, 2004). Iglesias cuyas plantas y soluciones son muy similares a las contemporáneas iglesias de San Miguel de Escalada y de San Cebrián de Mazote, levantadas, precisamente, por monjes procedentes de Hispania, como ya se ha visto.

Por otro lado, la geografía de concentración de inscripciones en la zona de Córdoba y Granada, durante el califato, coincide con la relación conocida de Obispos y obispados (SIMONET, 1983: III, 604ss; AILLET, 2010:375-, car. 1-2), y de las iglesias o comunidades cristianas mencionadas en el "Calendario de Córdoba" del año 961-2 (DOZY, 1961), pero sin embargo, contrasta con la geografía administrativo-territorial de la estructura eclesiástica cristiana oficial, la cual sigue manteniendo sus cabeceras en las sedes metropolitanas de Sevilla y Toledo, en donde se localiza el scriptorium toledano de donde se sabe proceden los Códices de "Trasamundo" del 902 y el dedicado a la Abadesa Gundissa del año 938 (GÓMEZ-MORENO, 1919: 359-360; AILLET, 2010: 144). Sedes Metropolitanas en las que, sin embargo y paradójicamente, no han aparecido hasta hoy en día ni una sola prueba epigráfica (GONZÁLEZ, 2002) o 
material de la presencia en las mismas de cristianos o de comunidades de cristianos no asimilados. Comunidades que debieron construir iglesias como lo confirma el "Calendario de Córdoba" del año, 961-2, en el que se mencionan casi una docena de iglesias en Córdoba y en su campiña (DOZY, 1961), pero de las que no se ha conservado nada (PÉREZ, 2012). Vacío acompañado de la ausencia de información sobre la existencia de scriptorium en estas comunidades religiosas, ya que no se conoce ni un solo códice o Beato proveniente de Córdoba o de Granada, en esos años; aunque sí, coincidiendo con la diáspora de finales de siglo, podemos mencionar la Biblia Hispalense, del año 988 (GÓMEZ-MORENO, 1919: 358-9) (Fig. 9B).

Biblia Hispalense en la que aparece varias veces la representación de un "pavón con pez e inscripción árabe en el cuello" (GÓMEZMORENO, 1919: 359, fig. 191), cuya forma y tratamiento nos recuerda, precisamente, a los aguamaniles metálicos, como el ejemplar que se conserva en el Museo del Louvre que porta en el mismo lugar su inscripción bilingüe y de una cronología del año 972 en la que consta que lo realizó 'Abd al-Malik al-Nașrãnî, es decir el "cristiano" (AZUAR, 2015: 133-4). Así también resulta interesante la hipótesis planteada por D. Anedda y A. Pala, en cuanto se refiere a la "cruz patada" que decora el buche o pecho el aguamanil de Cagliari y su decoración vegetal, que presenta evidentes similitudes con la escultura decorativa de las iglesias de San Miguel de Escalada (León) y de Santianes de Pravia (2014: 715). Iconografía, forma y cronología que reforzaría la procedencia andalusí de los tres ejemplares de aguamanil conocidos, y su autoría cristiana (AZUAR, 2004: 125-7; 2011: 189-190; 2015:133-4). Objetos litúrgicos producidos por los cristianos de al-Andalus, a finales del siglo X o principios del siglo XI, en un lugar impreciso de la geografía andalusí, para las comunidades o monasterios ya sea de los reinos cristianos del norte $\mathrm{O}$, a través de comerciantes amalfitanos, a las repúblicas italianas, como sería el caso del aguamanil hallado en Mores (Cerdeña) (ANEDDA, 2012; ANEDDA, PALA, 2014:721)

\section{VI. "De Arqueología Mozárabe" o de los cristianos bajo el califato de al-Andalus}

La arqueología de los registros epigráficos pone de manifiesto y en primer lugar que nos encontramos ante los primeros restos materiales de la pervivencia de comunidades de cristianos no asimilados en el interior de alAndalus que, aun estando arabizados (AILLET, 2012: 153ss), se identifican o manifiestan en sus lápidas funerarias para la posteridad en "latín" y en un contexto tardío de la segunda mitad del siglo $X$, cien años después de los martirios de Córdoba y con posterioridad a la represión de las revueltas muladíes de fines del siglo IX y del aplastamiento de la sublevación de Ibn Hafsún.

Una geografía epigráfica muy concreta y concentrada, como se ha visto, situando a estas comunidades en Córdoba y su serranía, y cuyas inscripciones nos confirman que nos hallamos ante cristianos que viven en comunidades cenobíticas de tipo familiar o muy reducidas, en complejos eremíticos o en monasterios, ya sean de hombres o de mujeres (MARTÍNEZ TEJERA, 2003). Comunidades monásticas de donde seguramente procedería la campana donada por un desconocido Abad Samsón al monasterio de San Sebastián en el año 955, o quizás el candil con la inscripción "Opus Salomonis era T", de una cronología de los años 962-972, como vimos en el artículo anterior (AZUAR, 2015: 131-133) (Fig. 10).

La concentración de estas comunidades, bajo el califato, en Córdoba y en sus montañas, en eremitorios o monasterios (AILLET, 2010: 70ss), viene a poner nuevamente sobre la mesa la hipótesis del profesor Mikel de Epalza (1985-6, 1994; EPALZA, LLOBREGAT, 1982), muy discutida (AILLET, 2010: 16-7; REAL, 2014). Es decir, ante situaciones de ausencia de comunidades importantes de cristianos, cohesionadas y organizadas, que impedirían el nombramiento de obispos, necesarios para asegurar su devenir eclesiástico y la santificación de los santos óleos de los rituales litúrgicos, -como sería el caso de al-Andalus en el siglo X, en dónde apenas está constatada la existencia en Sevilla del obispo Julián (937), 


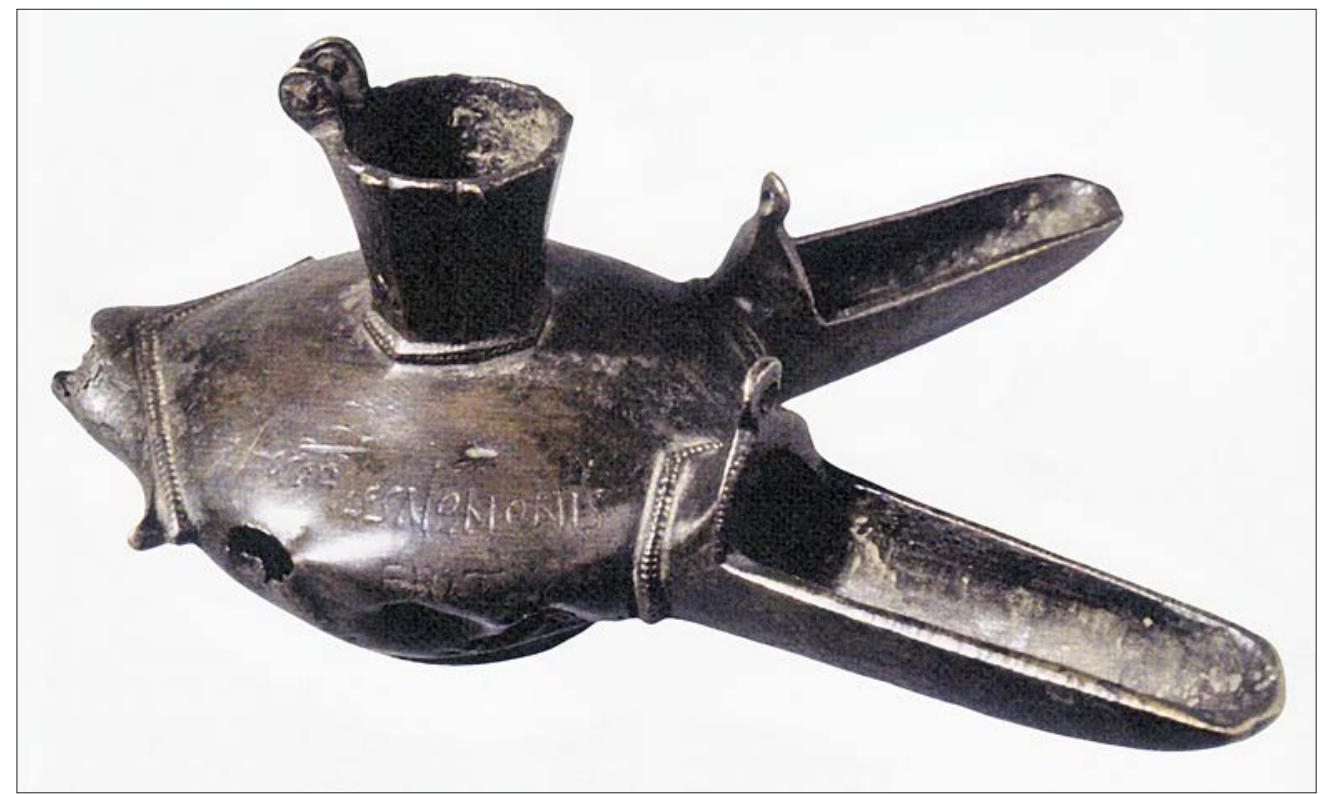

Fig. 10. Candil con la inscricpión "Opus Salomonis eraT" (MAN 50857)

de un arzobispo Juan en Toledo (m. 956) y de los obispos Juan (957) y Juan II (988) en Córdoba (SIMONET, 1983: III, 604ss; Aillet, 2010)-, sólo podrían nombrarse obispos en aquellas comunidades monásticas y entre sus monjes y abades, situación que, como se ha visto, sólo se daba en Córdoba, y además debían ser reconocidos por el propio califa, interesado en su control y no dudando de utilizarlos como traductores o como embajadores ante los reinos cristianos del norte de la Península o de Europa.

La excepcionalidad y la debilidad de estas comunidades cristianas queda patente no sólo por su exclusiva concentración en Córdoba, según los registros epigráficos, y por la ausencia de iglesias o monumentos, sino también por su dificultad para desarrollar su normal actividad religiosa, a la vista de los escasos, por no decir inexistentes, objetos rituales conocidos hasta el momento en el interior de al-Andalus. Así, resulta sorprendente que no conozcamos, ni se han hallado, un solo ejemplar de jarro ni de pátena cristianos de los siglos IX-X en el interior de al-Andalus. Objetos que, sin embargo, eran frecuentes en época visigoda hasta la conquista islámica de la Península, como lo confirman el medio centenar de estos jarritos litúrgicos o "vasos rituales" de época visigoda, en su mayoría de bronce, que se conservan y han sido estudiados (PALOL, 1950, 1961-2; BALMASEDA, PAPI, 1997), y que se distribuyen por toda la amplia geografía peninsular, no sólo por las tierras de León, sino también por el sur, como serían, por citar algunos ejemplos, los interesantes conjuntos rituales hallados en Pesqueras (Segovia), o en el complejo monástico de "El Gatillo" (Cáceres) (BALMASEDA, PAPI, 1997). "Vasos rituales" que, como puso de relieve en su día P. Palol (1950: 26-7) y en atención a sus inscripciones, están vinculados estrechamente a la ordenación por el Obispo de Diáconos y Subdiáconos, a quienes iban dedicados. Objetos que además, como ya propusieron en su día M. Gómez-Moreno y J. Ferrándis (BALMASEDA, PAPI, 1987: 167-8), eran utilizados en el bautismo y en la comunión de los fieles, como así se atestigua en los textos eclesiásticos, a la vista del análisis efectuado por R. Puertas Tricas en su interesante estudio sobre "Terminología arqueológica en los concilios hispano-romanos y visigodos” (1966).

A la ausencia de estos objetos rituales en el territorio andalusí, que refuerza la hipótesis de la ausencia de Obispos, hay que suponer la dificultad para el desarrollo de la actividad litúrgico-ritual de los cristianos a la vista de la 
inexistencia arqueológica de ejemplares del resto de las "preseas eclesiásticas", identificada por M. Gómez-Moreno en el capítulo X, de su obra sobre las iglesias mozárabes (1919: 321ss). Nos referimos precisamente a los "vasa sacra" o los cálices, de los que no se ha conservado ninguno de época visigoda, quizás por haber sido fundidos (BALMASEDA, PAPI, 1998), pero sin embargo sí en época islámica, aunque no en el interior de al-Andalus, sino en la catedral de Braga (Portugal), en donde se encuentran el "cáliz y la pátena de San Geraldo" que, por su inscripción y por hallarse en el interior del conocido bote de marfil califal de Sayf al-Dawla (BOHEM, LITTLE, 1993), se les puede considerar como un presente de 'Abd al-Malik, hijo de Almanzor, al conde Mendo, entre los años 1004-1008, como ya hemos tenido ocasión de analizar en el artículo anterior (AZUAR, 2015: 137-8)

Al igual que este cáliz, los otros objetos rituales inequívocamente cristianos se encuentran no en al-Andalus, sino en los territorios de la frontera con los reinos cristianos. Como sería el caso de la excepcional "cruz votiva de San Millán", ya analizada (AZUAR, 2015: 135-6), realizada en marfil y de la que se conocen sólo tres brazos, que responde al tipo de gran cruz patada procesional, siguiendo el modelo precedente de la cruz votiva de Santiago de Peñalba, de los años 931-951 (MARTÍNEZ TEJERA, 2000-2001: 382, n¹43). La cruz está considerada como un regalo del califa de Córdoba para la fundación del monasterio de San Millán (984) y por tanto de fines del siglo X (AZUAR, 2015). De similar cronología, sería el "ara de altar", también de San Millán, conservada en el Museo Arqueológico Nacional, con no inv. 63936 (FRANCO, 1992: 80).

La arqueología de estos objetos rituales litúrgicos, su existencia o no, así como la diferente tipología de los documentos epigráficos, -en donde se observa que de al-Andalus sólo proceden inscripciones funerarias, frente a las estelas fundacionales que se concentran en las fronteras septentrionales del califato-, y la ausencia de iglesias en el interior de alAndalus, si exceptuamos las de Bobastro, destruidas en el 928, etc nos sitúan ante la evidencia arqueológica de un cristianismo "dual" en al-Andalus. Dualismo generado en la Península tras la instauración del estado tributario islámico del califato omeya en al-Andalus que supuso la emigración masiva de cristianos, tras la represión de las revueltas muladíes de finales del siglo IX y principios del siglo X, hacia las tierras de la frontera septentrional de alAndalus en donde, bajo la complacencia y la protección de los emergentes reinos de León y Castilla (AILLET, 2010: 347ss), fueron capaces de desarrollar un arte de repoblación o de resistencia (MARTíNEZ TEJERA, 2003), levantando iglesias, con un programa decorativo propio y de marcado influjo andalusí, totalmente diferente al arte oficial de la monarquía asturiana que, en contra de la opinión de I. Bango y de su escuela, debemos considerar como el verdadero de los "mozárabes", denominados así en las fuentes escritas leonesas (GÓMEZMORENO, 1919, AILLET, 2010: 3) y de conformidad con la opinión de diversos investigadores que consideran el uso de este término y de aplicación exclusivamente a estos cristianos de la periferia de al-Andalus (HITCHCOK, 1981, 2008; LAPIEDRA, 1997: 308-312). Cristianismo que fue capaz de generar un "mozarabismo" como epifenómeno geográfico-cultural periandalusí y de exilio, de dilatada duración a lo largo de los siglos X y XI, hasta ser asimilado por la nueva y expansiva iglesia de conquista que, bajo el reinado de Alfonso VI y con la implantación del "románico" a finales del siglo XI, les prohibió sus antiguos ritos litúrgicos de raíz hispana (MARTíNEZ TEJERA, 1996; AILLET, 2010: 301ss), así como fue capaz de instaurar su legitimidad eclesiástica apropiándose, paradójicamente, de las reliquias de los antiguos mártires de Córdoba, como sucedió con las de San Zoilo, Félix y el obispo de Córdoba Agapio que fueron trasladadas al monasterio de Carrión de los Condes en Zamora, o con las de los mártires Nunilio y Alodia cuyos restos fueron trasladados al monasterio de Leyre (Pamplona) y conservados en el interior de su extraordinaria arqueta de marfil, entre otros (ROSSER-OWEN, 2015:50ss).

Al mismo tiempo, aquellos cristianos que no emigraron y se mantuvieron como dimmî y protegidos del Califa de Córdoba, sobrevi- 
vieron en parte en reducidas comunidades cenobíticas o practicando vida eremítica en los montes de Córdoba, primero, y después, a finales del siglo $X$, tras su diáspora en los apartados lugares de la Alpujarra Granadina y de la serranía de Málaga. Cristianos que apenas han dejado rastro arqueológico de sus iglesias, ni de sus cementerios, ni de sus "preseas eclesiásticas" u objetos necesarios para los ritos litúrgicos. Huella que tampoco se rastrea en las fuentes árabes, en las que nunca aparece el término de "mozárabe" para referirse a los cristianos de al-Andalus (Lapiedra, 1997). Por estas razones, no se les puede considerar como generadores de un movimiento o una "cultura mozárabe" en el interior de al-Andalus, sino más bien como los autores de contados objetos: tres campanas, un candil y varios excepcionales aguamaniles con forma de pavo real, identificadores de la existencia de cristianos, como así se constata en la inscripción del "pavón del Museo de Louvre", pero no de un cristianismo cohesionado y organizado (ACIÉN, 2009). Rasgos todos ellos de un "cripto-cristianismo" consentido, propio de una minoría resiliente y residual de dimmî o protegidos, hipertrofiado por la historiografía hispana oficial, pero en vías de desaparición ante la llegada de los "neo-mozárabes", bajo la dinámica socio-cultural y económica de las Taifas (EPALZA, 1985-6; 1994) y que a finales del siglo X comenzaran a dar muestras arqueológicas de su condición de "arabizados", a la vista de las primeras lápidas con inscripción bilingüe en árabe y en latín como se ha visto. Confiamos en que la revisión analítica efectuada de la centenaria obra de M. Gómez Moreno intitulada "De Arqueología Mozárabe" y de los contados registros arqueológicos y materiales conocidos en la actualidad (ACIÉN, 2009) hayan supuesto una aportación clarificadora a la necesidad planteada en su día por la profesora Ma Jesús Viguera (2008), de que la arqueología debía incorporase al debate y conocimiento de la identidad de aquellos cristianos arabizados, pero no asimilados, del califato de al-Andalus.

\section{BIBLIOGRAFÍA}

ACIÉN, Manuel (1994): Entre el feudalismo y el Islam: Umar ibn Hafsun en los historiadores, en las fuentes, en la historia. Universidad de Jaén. Jaén

-- (2009): "Consideraciones sobre los mozárabes de al-Andalus", Studia historica. Historia medieval, 27, (Salamanca), pp. 23-36

AILLET, Cyrille (2009): "El monasterio de Lorvâo y los confines de la Beira (siglos IX-XII). Apuntes sobre la memoria histórica de un espacio de contacto", Studia historica. Historia medieval, 27 (Salamanca), pp. 71-95

-- (2010): Les Mozárabes. Christianisme, Islamisation et Arabisation en Péninsule Ibérique (IX-XIle siècle). Casa de Velázquez, Madrid

AILLET, C.; PENELAS, M.; ROISSE, Ph. (Eds) (2008): ¿Existe una identidad Mozárabe?. Historia, lengua y cultura de los cristianos de al-Andalus (siglos IX-XII), Casa de Velázquez. Madrid

ALMAGRO, Martín (1976): "Antigüedades de Mérida en el Museo Arqueológico Nacional”, Augusta Emerita. Actas del Bimilenario de Mérida, Ministerio de Educación y Ciencia, (Madrid), pp. 127-139

ALONSO, Fernán; CABALLERO, Luis; RODRÍGUEZ, Eduardo (1997): "Cronología de la iglesia mozárabe de S. Baudelio de Berlanga (Soria): primeros resultados de dendrocronología y carbono 14", Boletín de Arqueología Medieval, 11 (Madrid), pp. 249-263

AMADOR DE LOS RIOS, José (1877): Monumentos LatinoBizantinos de Mérida. Real Academia de Bellas Artes de San Fernando, Madrid

AMADOR DE LOS RIOS, José; AMADOR DE LOS RIOS, Rodrigo (1879): Monumentos Latino-Bizantinos de Córdoba. Real Academia de Bellas Artes de San Fernando, Madrid

AMORÓS, Victoria; CAÑAVATE, Victor (2010): “Transformación funcional de espacios representativos en los inicios del emirato. La Basílica y el espacio episcopal de El Tolmo de Minateda", en I Congreso Internacional Espacios urbanos en el Occidente Mediterráneo (ss. VI-VIII) (Toledo), pp. 191-198

ANEDDA, Damiano (2012): "Bronces zoomorfos islámicos en Italia", Anales de Historia del Arte, 22, II (Madrid), pp. 41-55

ANEDDA, Damiano; PALA, Andrea (2014): "Aquamanili nella liturgia cristiana (IV-XVI secolo): il bronzo della Pinacoteca Nazionales di Cagliari", Anuario de Estudios Medievales, 44/2 (Barcelona), pp. 689-731

ARCE, Fernando (1992): "Los monasterios cordobeses de Tábanos y Peñamelaria a la luz de los textos y su entorno histórico", Boletín de Arqueología Medieval, 6 (Madrid), pp. 157-170

-- (2000): "Viejas y nuevas perspectivas sobre la cultura material mozárabe", Luis CABALLERO, Pedro MATEOS (eds.) (2000): Visigodos y Omeyas. Un debate entre la Antigüedad Tardía y la Alta Edad Media. Anejos de AEspA, XXIII, (Madrid), pp. 77-93, 
AZUAR, Rafael (2004): "Pavones, gallos y grifos en la metalistería islámica”, Maria Amor FOMBELLA (ed.), El Gallo de la Torre. San Isidoro de León. (León, 2002) pp. 119-134

-- (2011): "Inscripciones, símbolos y usos cristianos de la cultura material islámica" en Rosa VARELA, Mario VARELA, Catarina TENTE: Cristiâos e Muçulmanos na Idade Média Peninsular.Encontros e Desencontros (Lisboa), pp. 187-198

-- (2015): "De Arqueología Mozárabe. I", Arqueología y Territorio Medieval, 22 (Jaén), pp. 121-145

BALMASEDA, Luis J.; PAPI, Concepción (1997): “Jarritos y patenas de época visigoda en los fondos del Museo Arqueológico Nacional", Boletín del Museo Arqueológico Nacional, XV, 1-2, (Madrid), pp. 153- 174

-- (1998): "Cruces, incensarios y otros objetos litúrgicos de épocas paleocristiana y visigoda en el Museo Arqueológico Nacional" Boletín del Museo Arqueológico Nacional, XVI, 1-2 (Madrid), pp. 119-142

BANGO, Isidro G. (1974): "Arquitectura de la décima centuria: ¿repoblación o mozárabe?”, Goya nº 122, (Madrid), pp. 68-75.

-- (2001): Arte Prerrománico Hispano. El arte en la España cristiana de los siglos VI al XI. Summa Artis, Espasa Calpe. Madrid. Vol. VIII-II

BARCELÓ, Carmen (2001): “Columnas 'arabizadas' en basílicas y santuarios del occidente de al-Andalus", La isamización de la Extremadura romana. Cuadernos Emeritenses,17, (Mérida), pp.87-137

-- (2002): "Escritos árabes en la Basílica Paleocristiana de Casa Herrera (Mérida)", Madrider Mitteilungen, 43 (Madrid), pp. 299-315

BELTRÁN, José; LÓPEZ, José R. (coords.) (2003): El museo cordobés de Pedro Leonardo de Villacevallos: el coleccionismo arqueológico en la Andalucía del siglo XVIII, Real Academia de la Historia, Málaga

BOHEM, B.D.; LITTLE, Charles T. (1993): "Chalice and Paten of San Geraldo, pyxis of Sayf al-Dawla", The Art of Medieval Spain A.D. 500-1200, Metropolitan Museum of Art. (New York), pp. 148-9, no 73

CABALLERO, Luis (1987): "Hacia una propuesta tipológica de los elementos de la arquitectura del culto cristiano" II Congreso Arqueología Medieval Española, I, (Madrid) pp. 61-98

-- (ed.) (1990): Los bronces romanos en España. Ministerio de Cultura Madrid

-- (1998): "Arquitectura visigótica y musulmana. ¿Continuidad, concurrencia o innovación?", Ruptura o Continuidad, pervivencias preislámicas en al-Andalus, Cuadernos Emeritenses, 15 (Mérida), pp. 143-176

-- (2000): "La arquitectura denominada de época visigoda ¿es realmente tardorromana o prerrománica?" en CABALLERO, L.; MATEOS, P. (eds.) (2000): Visigodos y Omeyas. Un debate entre la Antigüedad Tardía y la Alta Edad Media. Anejos de AEspA, XXIII (Madrid), pp. 207-248
-- (2001): "Aportación a la arquitectura medieval española. Definición de un grupo de iglesias castellanas, riojanas y vascas", V Congreso de Arqueología Medieval Española, 1 (Valladolid), pp. 221-233.

-- (2006): "El conjunto monástico de Santa María de Melque (Toledo). siglos VIII-IX (criterios seguidos para la identificación de monasterios hispánicos tardo antiguos)", en J.A. GARCIA DE CORTÁZAR, R. TEJA (Coords): Monjes y Monasterios hispanos en la Alta Edad Media, (Fundación Santa Maria la Real, Palencia) pp. 99-146

-- (2011): "Acerca del paisaje arquitectónico hispánico inmediato al año 711 (entre Toledo y el territorio Astur y Vasco)", 711 Arqueología e Historia entre dos mundos. Zona Arqueológica, no 15, I (Alcalá, Madrid), pp.255-271

-- (2013): "Producciones constructivas y decorativas. Indicadores crono-culturales de la alta Edad Media Hispánica", Archivo Español de Arqueología, 86 (Madrid), pp. $187-214$

CABALLERO, Luis; MATEOS, Pedro (eds.) (2000): Visigodos y Omeyas. Un debate entre la Antigüedad Tardía y la Alta Edad Media. Anejos de AEspA, XXIII, Madrid

CABALLERO, Luis; SÁEZ, Fernando (1999): La iglesia mozárabe de Santa María del Trampal, Alcuescar (Cáceres), Consejería de Cultura. Mérida

CABALLERO, Luis; UTRERO, Ma de los Ángeles (2013): "El ciclo constructivo en la Alta Edad Media Hispánica. Siglos VIII-IX", Archeologia dell'Architecttura, XVIII, (Firenze), pp. 127-146

CAMÓN, José (1963): "Arquitectura española del siglo X. Mozárabe y de la repoblación”, Goya, 52, (Madrid), pp. 206-219.

CASTEJÓN, Rafael (1949): "Excavaciones en monasterios mozárabes de la sierra de Córdoba", Boletín de la Real Academia de Ciencias, Bellas Letras y Nobles Artes de Córdoba, 61 (Córdoba), pp. 65-76

CAVEDA, José (1848): Ensayo histórico de la Arquitectura Española. Imprenta de D. Santiago Saunaque, Madrid

CHALMETA, Pedro (2003): Invasión e Islamización. La sumisión de Hispania y la formación de al-Andalus, Universidad de Jaén. Jaén

CORRAL, Jose L. (1981): "Rutas arquitectónicas mozárabes en Alcalá de Moncayo (Zaragoza)", Turiaso, 2 (Teruel), pp. 141-172

CRESSIER, Patrice (1991): "El renacimiento de la escultura de capiteles en época Emiral: entre Occidente y Oriente", Cuadernos de Madînat al-Zahrâ', 3 (Córdoba), pp. 165-187

DOZY, Reinhart (1961): Le Calendrier de Cordoue. Ed. Ch. Pellat. . E. J. Brill. Leiden

EPALZA, Mikel de (1985-6). "La islamización de al-Andalus: Mozárabes y Neomozárabes", Revista del Instituto Egipcio de Estudios Islámicos en Madrid, XXIII, (Madrid), pp. 171-179

-- (1994): "Falta de Obispos y conversión al Islam de los cristianos de al-Andalus”, Al-Qanțara, XV-2 (Madrid), pp. 385-400 
EPALZA, Mikel de; LLOBREGAT, Enrique (1982): “ ¿Hubo mozárabes en tierras valencianas? Proceso de islamización del Levante de la Península (Sharq al-Andalus)", Revista del Instituto de Estudios Alicantinos, 36 (Alicante), pp. 7-31

ESTEBAN, Julio; SALAS, José (2003): Epigrafía romana y cristiana del Museo de Cáceres. Museo de Cáceres. Cáceres

EWERT, Christian; CRESSIER, Patrice; ZOZAYA, Juan (eds) (1990): Coloquio internacional de capiteles corintios prerrománicos e islámicos (ss. VI-XII dC). Ministerio de Cultura, Madrid

FERNÁNDEZ, Javier (2009): "Los mozárabes en el Reino de León: siglos VIII-XI”, Studia Historicae. Historia Medieval, 27 (Salamanca), pp. 53-69

FITA, Fidel (1914): "Alcaracejos, Adamuz y Córdoba. Nuevas inscripciones", Boletin de la Real Academia de la Historia, LX (Madrid), pp. 557-572 (ed. digital http:// www.cervantesvirtual.com/portales/boletin_real_academia_historia/obra/alcaracejos-adamuz-y-cordobanuevas-inscripciones--0/; Consultado, 5 de febrero 2016

FOMBELLA, Ma Amor (ed.) (2004): El Gallo de la Torre. San Isidoro de León. León

FONTAINE, Jacques (1978): La España Románica. X. El Mozárabe. Ediciones Encuentro, Madrid

FRANCO, Ma Ángela (1992): "Antigüedades cristianas de los siglos VIII al XV", Museo Arqueológico Nacional. Guía General, II (Madrid), pp. 75-111

GALLEGO, Ma del Mar (coord.) (2009): La Vega Baja de Toledo, Toletum Visigodo D.L., Toledo

GARCÍA, Vicente; CAVERO, Gregoria (coords.) (2014): San Miguel de Escalada (913-2013), Universidad de León. León

GARCIA DE CORTÁZAR, Jose Antonio; TEJA, Ramón. (Coords) (2006): Monjes y Monasterios hispanos en la Alta Edad Media, Fundación Santa Maria la Real. Palencia

GÓMEZ, Manuel (1888): Medina Elvira. Granada (Ed. facsímil, 1988)

GÓMEZ-MORENO, Manuel (1907-1908): "Santo Tomás de las Ollas", Boletín de la Sociedad Castellana de Excursiones, III (Valladolid), pp. 401-403

-- (1913): "De Arqueología Mozárabe", Boletín de la Sociedad Española de Excursiones, 21-2 (Madrid), pp. 89-116

-- (1919): Iglesias Mozárabes. Arte Español de los Siglos IX al XI, Madrid (reed.facs. Granada, 1975).

-- (1951): El arte español hasta los Almohades. Arte Mozárabe, ARS HISPANIAE, I I I (Madrid), pp. 355-409

GONZÁLEZ, Julián (2002): "La epigrafía mozárabe: testimonio de una minoría religiosa”, en M. PÉREZ (coord.), Actas del III Congreso Hispánico de Latín Medieval: (León, 26-29 de septiembre de 2001), 2, (León) pp. 741-752

GUTIÉRREZ, Sonia (2011): "El Tolmo de Minateda en torno al 711", en 711 Arqueología e Historia entre dos mundos. Zona Arqueológica, nº 15, I (Madrid), pp. 353-372

GUTIÉRREZ, Sonia; ABAD, Lorenzo; GAMO, Blanca (2005):

"Eio, Iyyuh y el Tolmo de Minateda (Hellín, Albacete): de sede episcopal a madîna islámica", en Les ciutats tardoantiques d'Hispania: cristianització i topografía. VI Reunió d’Arqueologia Cristiana Hispánica (Barcelona), pp. 345-368

HITCHCOK, Richard (1981): “Quiénes fueron los verdaderos mozárabes?. Una contribución a la historia del mozarabismo", Nueva Revista de Filología Hispánica, XXX 2 (México), pp. 574-583

-- (2008): Mozarabs in Medieval and Early Modern Spain Identities and Influences. Ashgate, Aldershot-Hampshire

HÜBNER, Aemilius, (1871): Inscriptiones Hispaniae Christianae. Berolini apud Georgium Reimerum

-- (1900): Inscriptionum Hispaniae Christianorum Suplementum. Berolini Typis et impensis Georgii Reimeri

IZQUIERDO, Ricardo (2009): “'De complejo palatino a arrabal islámico?”, en Ma del Mar GALLEGO (coord..) La Vega Baja de Toledo, (Toledo), pp. 95-109

-- (2011). "Toledo en torno al 711", en 711 Arqueología e Historia entre dos mundos. Zona Arqueológica, no 15, I (Madrid), pp. 375-386

JUAN, Empar; LERMA, José V. (2000): "La villa áulica del Pla de Nadal (Riba-roja del Túria)", en Albert V. RIBERA(ed): Los orígenes del cristianismo en Valencia y su entorno, (València), pp. 135-142

LAMBERT, Élie (1939): “La Civilisation Mozárabe”, Hommage à Ernest Martinenche: études hispaniques et américaines, (Paris), pp. 34-46

LAMPÉREZ Y ROMEA, Vicente. (1908): Historia de la Arquitectura Cristiana Española en la Edad Media. Vol. I. J. Blass y cía, Madrid, 2 vols. (Ed. Facsímil, Ámbito Eds. Valladolid, 1999) (http://bildsuche.digitale-sammlungen. de/index.html?c=viewer\&bandnummer=bsb0006693 $6 \&$ pimage $=748 \& v=150 \& n a v=\& l=e n)$. Consultado 4 de marzo 2016

LAPIEDRA, Eva (1997): Cómo los musulmanes llamaban a los cristianos hispánicos. Instituto Juan Gil Albert. Alicante

León (2000-2001): Maravillas de la España Medieval. Tesoro Sagrado y Monarquía, León.

LARRÉN, Hortensia; CAMPOMANES, Emilio (2014): "San Miguel de Escalada a través de su arqueología, valoración de sus trabajos (1983-2004)", en V. GARCIA, G. CAVERO (coords.): San Miguel de Escalada (913-2013), pp. 85-122

LÉVI-PROVENÇAL, Évarist (1987): España Musulmana hasta la caída del califato de córdoba (711-1031 de J.C.). Instituciones y vida social e intelectual, en R. Menéndez Pidal: Historia de España, V (Madrid), pp. 1-330, 5a ed.

Lisboa (1998): Portugal Islâmico. Os últimos sinais do Mediterrâneo, Museo Nacional de Arqueologia, Lisboa

MANZANO, Eduardo (2006): Conquistadores, Emires y Califas. Los Omeyas y la formación de al-Andalus. Crítica. Barcelona

MARFIL, Pedro (2000): "Córdoba de Teodosio a 'Abd alRahmãn III", en L. CABALLERO, P. MATEOS (eds.) (2000): Visigodos y Omeyas. Un debate entre la Antigüedad Tardía y la Alta Edad Media. Anejos de AEspA, XXIII, (Madrid), pp. 117-141 
MARTÍNEZ, Gonzalo (2011): "La emigración mozárabe al Reino de León. Siglos IX-X”, Mozárabes. Identidad y continuidad de su historia. Antigüedad Cristiana, XXVIII (Murcia), pp. 99-117

MARTÍNEZ ENAMORADO, Virgilio (2003): Al-Andalus desde la periferia. La formación de una sociedad musulmana en tierras malagueñas (siglos VIII-X). Diputación de Málaga. Málaga

-- (2004): "Sobre las 'cuidadas iglesias' de Ibn Hafsûn. Estudio de la basílica hallada en la ciudad de Bobastro (Ardales, Málaga)", Madrider Mitteilungen, 45 (Madrid), pp. 507-531

-- (2012): 'Umar ibn Hafsûn. De la rebeldía a la construcción de la Dawla. Estudios en torno al rebelde de al-Andalus (880-928). Cátedra Ibn Khaldun. Costa Rica

MARTÍNEZ NÚÑEZ, Ma Antonia (2014): "Las fuentes epigráficas. Siglos IX-X”, Jábega, 105 (Málaga), pp. 59-73

MARTÍNEZ TEJERA, Artemio M. (1996): "Dedicaciones, consagraciones y Monumenta consecrationes (siglos VIXII): testimonios epigráficos altomedievales en los antiguos reinos de Asturias y León", Brigecio, 6 (Benavente, Zamora), pp. 77-102

-- (2000-2001). "Cruz votiva de Santiago de Pañalba", en Maravillas de la España medieval. Tesoro sagrado y monarquía, I (León), p. 382, nº 143

-- (2003): "La arquitectura de la comunidad Dimmiyyun (siglos IX-X): 'arquitectura del Pacto' y 'arquitectura de resistencia'", Codex Aquilarensis, 19 (Aguilar de Campo), pp. $47-72$

-- (2011): "La Arquitectura cristiana del siglo X en el Reino de León (910-1037): de 'Mozárabe' a 'Arquitectura de Fusión' ", Mozárabes, Identidad y continuidad de su historia. Antigüedad y Cristianismo, XXVIII (Murcia), pp. 163-229

-- (2016): Estudios sobre las 'iglesias arabizadas' del siglo X en el reino de León. Editorial académica Española. Berlín

MATEOS, Pedro; ALBA, Miguel (2011): “El paisaje urbano de Mérida en torno al 711", en 711 Arqueología e Historia entre dos mundos. Zona Arqueológica, n 15, II (Madrid), pp. 27-38

MENÉNDEZ, José (1956): "Las pinturas prerrománicas de la iglesia de Santiago de Peñalba”, Archivo Español de Arte, XXIX (Madrid), pp. 291-295.

MENÉNDEZ, Ramón (dir.) (1987): Historia de España, V, Espasa-Calpe. Madrid, 5a ed.

MERGELINA, Cayetano de (1925): "De Arquitectura Mozárabe. La iglesia rupestre de Bobastro", Archivo Español de Arte y Arqueología, 2 (Madrid), pp. 159-176

-- (1927): Bobastro. Memoria de las excavaciones efectuadas en las Mesas de Villaverde. El Chorro (Málaga), Junta Superior de Excavaciones y Antigüedades, Madrid, no 89

Mértola (2014): O Sudoeste Peninsular. Entre Roma e o Islaô, Campo Arqueológico de Mértola. Mértola. Catálogo ed. CD-ROM
MOLINA, Luis (1983): Una descripción Anónima de alAndalus. CSIC. Instituto Miguel Asín. Madrid, 2 vols.

NAVAL, Francisco (1914): "Lápidas mozárabes de Córdoba", Boletin de la Real Academia de la Historia, LX (Madrid), pp.466-470 (Ed. digital. http://www.cervantesvirtual.com/portales/boletin_real_academia_historia/ obra/lapidas-mozarabes-de-cordoba--0/; consultado el 5 de febrero 2016)

New York (2003): The Art of Medieval Spain A.D. 500-1200, Metropolitan Museum of Art. New York

NOACK-HALEY, Sabine (1990): "Capiteles mozárabes", en EWERT, Ch.; CRESSIER, P.; ZOZAYA, J. (eds) (1990): Coloquio internacional de capiteles corintios prerrománicose islámicos (ss. VI-XII dC). (Madrid), pp. 37-52

PALOL, Pedro de (1950): Bronces hispanovisigodos de origen Mediterráneo. I. Jarritos y Patenas litúrgicos. Consejo Superior, Barcelona

-- (1961-2): "Los bronces litúrgicos hispanovisigodos y sus perduraciones", Homenaje al Profesor Cayetano de Mergelina, (Murcia), pp. 699-710

-- (1990): "Bronces cristianos de época romana y visigoda en España”, Luis CABALLERO (ed.): Los bronces romanos en España. (Madrid), pp. 137-152

PASTOR, Mauricio (2002): Corpus de inscripciones Latinas de Andalucía. IV. Granada. Junta de Andalucía. Sevilla

PÉREZ, Maurilio (coord.) (2002): Actas del III Congreso Hispánico de Latín Medieval: (León, 26-29 de septiembre de 2001), León, 2 vols.

PÉREZ, Iván (2012): "Los Mozárabes de Córdoba del siglo IX: sociedad, cultura y pensamiento", Estudios Medievales Hispánicos, 1 (Madrid), pp. 177-220

PITA, Jose Manuel (1975): "Arte. La Edad Media”, en Castilla la Vieja León.I. Col. Tierras de España, (Barcelona), pp. 86-361

PUERTAS, Rafael (1966): "Terminología arqueológica en los concilios hispano-romanos y visigodos”, I Reunión Nacional de Arqueología Paleocristiana (Vitoria), pp. 199-221

-- (1979): "La iglesia rupestre de Las Mesas de Villaverde (Ardales, Málaga)”, Mainake, I (Málaga), pp. 179-216

-- (1986): "Los conjuntos rupestres mozárabes de Coín y Archidona”, Cuadernos de la Alhambra, XXI (Granada), pp. 11.53

-- (1987): "Iglesias rupestres de Málaga”, /l Congreso de Arqueología Medieval Española, I, (Madrid, 1987), pp.99-152

-- (1989): "Las iglesias rupestres de Málaga y el arte Mozárabe”, Jábega, 64 (Málaga), pp. 17-26

-- (1999-2000). "Iglesias prerrománicas hispánicas (siglos VIII al XI). Ensayo de tipología arquitectónica”, Mainake, XI-XII (Málaga), pp. 139-198

PUIG I CADAFALCH, Joan; DE FALGUERA, Antoni; GODAY I CASALS, J. (1909): L'Arquitectura Románica a Catalunya, Institut d’Estudis Catalans, Barcelona 
RAMÍREZ, Jose luis; MATEOS, Pedro (2000): Catálogo de las inscripciones cristianas de Mérida. Museo Nacional de Arte Romano. Mérida

REAL, Manuel L. (1995): "Inovaçâo e resistência: dados recentes sobre antiguidade cristâ no occidente peninsular", IV Reunió d'Arqueologia Cristiana Hispànica, Lisboa,1992. Barcelona, pp. 17-68

-- (1998): "Os moçarabes do Gharb portugués", Portugal Islâmico. Os últimos sinais do Mediterrâneo, (Lisboa), pp. 35-56

-- (2014): "Reflexôes sobre o moçarabismo no Gharb al-Andalus: o caso portugués" en O Sudoeste Peninsular. Entre Roma e o Islaô, Campo Arqueológico de Mértola. (Mértola), pp. 244-351,

RIBERA I LACOMBA, Albert V. (2005). "Origen i desenvolupament del nucli episcopal de València”, Les ciutats tardoantigues d'Hispania: cristianització i topografía. VI Reunió d'Arqueologia Cristiana Hispánica (Valencia), pp. 207-244

-- (Coord.) (2000): Los orígenes del cristianismo en Valencia y su entorno, Ajuntament, Valencia

-- (Coord.) (2015): Pla de Nadal (Riba-roja del Túria). El Palacio de Tevdinir. Ajuntament. Riba-roja del Túria_

RIBERA I LACOMBA, Albert V.; ROSSELLÓ, Miquel (2011). "Valencia y su entorno territorial tras el 713: epílogo visigodo", en 711 Arqueología e Historia entre dos mundos. Zona Arqueológica, no 15, 2 (Madrid), pp. 85-102

RIESCO, Angel (1988): "Tres lápidas funerarias con epígrafes latinos de los siglos IX-XI conservadas en la alcazaba de Málaga", Mainake, 10 (Málaga), pp. 185-212

RIU, Manuel (1975). "Poblados mozárabes de al-Andalus. Hipótesis para su estudio; el ejemplo de Busquístar", Cuadernos de Estudios Medievales, 2-3 (Granada), pp. 3-35

-- (1982): "Aportación de la arqueología al estudio de los mozárabes de al-Andalus", en M. RIU, C. TORRES, M. NIETO: 3 estudios de Historia Medieval andaluza (Córdoba), pp. 85-112

RIU, Manuel; TORRES, Cristóbal; NIETO, Manuel (1982): 3 estudios de Historia Medieval andaluza. Monte de Piedad y Caja de Ahorros de Córdoba. Córdoba

RODRÍGUEZ, Pedro (2003): "De Córdoba a Málaga: avatares de la colección arqueológica de Villacevallos", en J. BELTRÁN, J. R. LÓPEZ, (coords.), El museo cordobés de Pedro Leonardo de Villacevallos: el coleccionismo arqueológico en la Andalucía del siglo XVIII, (Málaga), pp. 335-362

ROSSER-OWEN, Marian (2015): "Islamic objects in christians contexts: relic translation and modes of transfer in Medieval Iberia", Art in Translation, 7-1(London), pp. 39-63

SÁNCHEZ, Isabel (2007): "La cristianización de las necrópolis de Cordvba. Fuentes escritas y testimonios arqueológicos", Archivo Español de Arqueología, 80 (Madrid), pp. $191-206$

SÁNCHEZ, Jerónimo (2006): Elementos arquitectónicos de época visigoda en el Museo Arqueológico de Córdoba. Arquitectura y Urbanismo en la Córdoba visigoda. Monografías del Museo Arqueológico de Córdoba, 1 (Córdoba)
SCHLUNK, Helmut; BERENGUER, Magin (1957): La pintura mural asturiana de los siglos IX-X. Principado de Asturias, Oviedo

SERRANO, Encarnación; ATENCIA, Rafael (1981): Inscripciones latinas del Museo de Málaga, Ministerio de Cultura, Madrid

SIDARUS, Adel; TEICHNER, Felix, (1997): "Termas romanas no Gharb al-Andalus. As inscriçôes árabes de Milreu (Estói)", Archeologia Medieval, 5 (Mértola, Portugal), pp. $117-189$

SIMONET, Francisco J. (1983): Historia de los mozárabes de España. Ed. Turner, Madrid (ed.Facsímil, de la de 1897-1903), IV vols.

SORIANO, Rafaela et al. (1998): Cripta arqueológica de la Cárcel de San Vicente. Ajuntament. València

TERRASSE, Henri (1932): L'Art Hispano-Mauresque des origines au XIIIe siècle, Institut des Hautes Etudes Marrocaines, XXV. Paris

TORRES, Leopoldo (1936): "Los modillones de lóbulos, Ensayo de análisis de la evolución de una forma arquitectónica a través de diez y seis siglos", Archivo Español de Arte y Arqueología, 34 (Madrid), pp. 1-62; (1985), Obra dispersa. II. Archivo Español de Arte y Arqueología, 9 (Instituto de España. Madrid.), pp. 159-289

-- (1958): "La pintura mural de las iglesias mozárabes", Al-Andalus, XXIII-2 (Madrid), pp. 417-424; (1983), Obra dispersa. Al-Andalus. Crónica de la España Musulmana, 6, (Instituto de España, Madrid). pp. 334-341

ULBERT, Thilo (1991): "Nachuntersuchungen im Bereich der frühchristlichen Basilika von Casa Herrera bei Mérida", Madrider Mitteilungen, 32 (Madrid), pp. 57-62

UTRERO, Ma de los Ángeles (2006): Iglesias Tardoantiguas y Altomedievales en la península ibérica. Análisis arqueológico y sistemas de abovedamiento, Anejos de AEspA, XL (Madrid)

VARELA, Rosa; VARELA, Mario; TENTE, Catarina (2011) Cristiâos e Muçulmanos na Idade Média Peninsular. Encontros e Desencontros. Instituto de Arqueologia e Paleociéncias, Lisboa

VELÁZQUEZ, Ricardo (1866): Discurso leído en la instalación de la Comisión de Monumentos Históricos y Artísticos de la provincia de León. León

VIDAL, Sergio (2011): "Lápida funeraria mozárabe con inscripción en Latín”, 711. Arqueología e historia entre dos mundos, Museo Arqueológico Regional. (AlcaláMadrid), pp. 262-3

VIGUERA, Ma Jesús (2008): "Existe una identidad Mozárabe? A modo de conclusión", en AILLET, C.; PENELAS, M.; ROISSE, Ph. (Eds): ¿Existe una identidad Mozárabe? Historia, lengua y cultura de los cristianos de al-Andalus (siglos IX-XII), (Casa de Velázquez .Madrid), pp. 299-316

ZOZAYA, Juan (1976): "Algunas observaciones en torno a la ermita de San Baudelio de Casillas de Berlanga", Cuadernos de la Alhambra, 12 (Granada), pp. 307-338

-- (2003): La ermita de San Baudelio de Berlanga. Soria. 